\title{
Environment and human subsistence in Northern France at the Late Glacial to early Holocene transition
}

\author{
Dorothée G. Drucker $^{1} \cdot$ Anne Bridault ${ }^{2} \cdot$ Thierry Ducrocq $^{3} \cdot$ Chris Baumann $^{4,5} \cdot$ Frédérique Valentin $^{6}$
}

Received: 12 December 2019 / Accepted: 3 July 2020 / Published online: 30 July 2020

(C) The Author(s) 2020

\begin{abstract}
The Late Glacial and early Holocene (ca. 15,000-6,000 cal BP) witnessed major changes in the environmental conditions which led to the establishment of temperate vegetation and animal species, thereby offering new subsistence opportunities to the population of hunter-gatherers. Measurements of the relative abundances in ${ }^{13} \mathrm{C}$ and ${ }^{15} \mathrm{~N}$ were applied to large herbivores from northern France to document the change in their habitat. During the early Holocene, red deer show a decrease in $\delta^{13} \mathrm{C}$ values most likely reflecting the effect of a dense canopy and an increase in $\delta^{15} \mathrm{~N}$ values probably linked to the increased soil activity of soils in foraged territories. Aurochs and roe deer $\delta^{13} \mathrm{C}$ values also revealed a more densely forested habitat at the end of the Preboreal, while the $\delta^{13} \mathrm{C}$ values of the wild boar indicate dependence on fruits and underground tubers that were not affected by the canopy effect. Three human individuals from Val-de-Reuil and La Chaussée-Tirancourt dated to the Preboreal period provided relatively high $\delta^{15} \mathrm{~N}$ values when compared with the local fauna and other early Mesolithic humans, which might have resulted from the consumption of freshwater resources especially at Val-de-Reuil. The $\delta^{34} \mathrm{~S}$ values appear to depend more on the geographical location of the individual, as demonstrated by the difference among wild boar $\delta^{34} \mathrm{~S}$ values between sites, rather than related to the protein source of the diet, namely, terrestrial versus aquatic. Our results confirm the influence of the forest ecosystem on the environment and diet of the considered early Mesolithic human of northern France, while the possible contribution of the aquatic ecosystem still needs to be documented.
\end{abstract}

Keywords Preboreal $\cdot$ Northern France $\cdot$ Stable isotopes $\cdot$ Environment $\cdot$ Diet $\cdot$ Aquatic resources

\section{Introduction}

Over the past decades, the stable isotope analysis of bone collagen has become a common tool of investigation of the subsistence of ancient hunter-gatherers(e.g., Richards 2002;

This article is part of the Topical Collection on Post-glacial human subsistence and settlement patterns

Electronic supplementary material The online version of this article (https://doi.org/10.1007/s12520-020-01149-4) contains supplementary material, which is available to authorized users.

Dorothée G. Drucker

dorothee.drucker@ifu.uni-tuebingen.de

Senckenberg Centre for Human Evolution and Palaeoenvironment at the University of Tübingen, Senckenberg Society for Nature Research, Hölderlinstrasse 12, 72074 Tübingen, Germany

2 UMR 7041, Archéologies Environnementales, CNRS, MSH Mondes René Ginouvès, 21 allée de l'Université, 92000 Nanterre, France
Bocherens 2009; Schulting 2011). Periods of climatic and/or cultural changes have especially been explored through the isotopic reconstruction of human diet, such as the Mesolithic to Neolithic transition (e.g., Lubell et al. 1994; Lillie and Richards 2000; Richards et al. 2003; Bonsall et al. 2004;
3 INRAP Hauts-de-France, 32 avenue de l'Étoile-du-Sud, F-80440 Glisy, France

4 Institute for Scientific Archaeology, University of Tübingen, Rümelinstrasse 23, 72070 Tübingen, Germany

5 Biogeology, Department of Geosciences, University of Tübingen, Hölderlinstraße 12, 72074 Tübingen, Germany

6 UMR 7041, Ethnologie Préhistorique, CNRS, MSH Mondes René Ginouvès, 21 allée de l’Université, 92000 Nanterre, France 
Bocherens et al. 2007; Fischer et al. 2007; Guiry et al. 2016). Indeed, the collagen ${ }^{13} \mathrm{C}$ and ${ }^{15} \mathrm{~N}$ abundances of a consumer depend on those of their food with a factor of enrichment, which is limited in ${ }^{13} \mathrm{C}$ (ca. 1\%) but significant in ${ }^{15} \mathrm{~N}$ (ca. 3 to $5 \%$ ) (e.g., Bocherens and Drucker 2003). Marine food resources are well characterized by higher ${ }^{13} \mathrm{C}$ and ${ }^{15} \mathrm{~N}$ abundances than food products of continental origins (e.g., Schoeninger and DeNiro 1984). Freshwater resources may be detected through higher ${ }^{15} \mathrm{~N}$ abundances than in terrestrial ones, while the ${ }^{13} \mathrm{C}$ abundances might provide overlapping ranges between the two sources (review in Guiry 2019). In the case of human consumers, the isotopic abundances of bone collagen can thus indicate the source of the dietary protein consumed over the last decade of their life (e.g., Hedges and Reynard 2007). More recently, the abundances in ${ }^{34} \mathrm{~S}$ have been considered for dietary reconstruction since marine resources display higher ${ }^{34} \mathrm{~S}$ than terrestrial ones (e.g., Richards et al. 2001). The freshwater resources, however, may or may not differ from the terrestrial ones depending on the context (e.g., Privat et al. 2007) and following a nonpredictable pattern since the ${ }^{34} \mathrm{~S}$ abundances in terrestrial resources depend on the geological context (review in Nehlich 2015). A very limited, if any, change in ${ }^{34} \mathrm{~S}$ abundances has been detected between a consumer and its diet (e.g., Richards et al. 2001; Krajcarz et al. 2019).

Isotopic investigation of human diet and environment has only recently focused on the Late Glacial to early Holocene transition in Europe. It was a period of abrupt climatic change between the last cold spell of the Younger Dryas (or GS-1, ca. 12,800-11,600 cal BP) characterized by an open steppe tundra landscape and the start of the global warming of the early Holocene during the Preboreal (ca. 11,600-9900 cal $\mathrm{BP})$. The increasing temperature and humidity allowed the development of a succession of forest formations (birch-pine woodland later replaced by broad-leaved forest) (e.g., Feurdean et al. 2014). This landscape development offered new opportunities for human subsistence through edible plants' elements, such as nuts and fruits; terrestrial preys such as red deer, roe deer, aurochs, wild boar, and elk; and productive aquatic ecosystems (e.g., Jarman 1972; Clarke 1976; Price 1987; Bridault 1994). Indeed, several zooarchaeology and stable isotope studies have revealed the importance of aquatic resources not only in coastal environments (Boethius et al. 2017) but also in inland contexts (Bazanella et al. 2007; Terberger et al. 2012, 2018; Drucker et al. 2016; Frontin 2017; Meadows et al. 2018). The estimation of the contribution of plants has been more elusive when considering bulk collagen, since plants provide far less protein than meat. Moreover, isotopic composition of vegetal dietary resources is not easy to reconstruct, since herbivorous animals reflect the consumption of other types of plants than those consumed by human individuals (see discussion in Bocherens 2009).
In this paper, we aim at documenting the impact of the climatic oscillations of the Late Glacial to the early Holocene on the habitat of large ungulates in northern France, and more specifically the red deer (Cervus elaphus), through the relative carbon- 13 and nitrogen- 15 abundances of their bone collagen. Such an investigation is also crucial to decipher the local isotopic baseline at the onset of the Holocene that will serve to interpret the isotopic composition of three human individuals from northern France. Direct dating of the animal specimens as well as the human individuals was also conducted to establish the chronological context. Finally, we applied sulfur-34 measurements to potentially gain more information on the diet and environment of the studied humans.

\section{Material and methods}

To reconstruct the local isotopic baseline in northern France over time, we identified and selected mature animal specimens. In a given site, when possible, the same anatomical part was preferred to avoid multiple sampling of the same individual (e.g., right metacarpus of aurochs from Belloy-surSomme). Organic preservation in the bone remains of the Somme Basin proved to be relatively poor, and only half of the initially selected samples provided collagen of required quantity and quality for the isotopic analyses. Altogether, we could retain 24 faunal samples, including red deer (Cervus elaphus, $n=13$ ), wild boar (Sus scrofa, $n=4)$, roe deer (Capreolus capreolus, $n=3$ ), aurochs (Bos primigenius, $n=$ 2), large bovid (Bos or Bison, $n=1$ ), and elk (Alces alces, $n=$ 1) from archaeological sites located in the Thérain valley a tributary of the Oise river (Warluis) and in the Somme Basin (Hangest-sur-Somme, Belloy-sur-Somme, Conty, Saleux, Pont-de-Metz, and Blangy; Table 1, Fig. 1). All these 24 remains were directly dated in addition to the zooarchaeological analysis and stable isotope investigation. To document further the Preboreal chronozone at the onset of the early Holocene, we have also included previously published data of red deer $(n$ $=1$ ), wild boars ( $n=4,2$ of them directly dated), and aurochs ( $n=1$, directly dated) from Henry-Farman, a Mesolithic site located in the Paris Basin (Leduc et al. 2013) in order to complete the terrestrial isotopic background. Remains of fish are very rare in northern France and generally post-date the Preboreal period, which could be due to the poor conditions of collagen preservation as observed on the mammal remains. In northern France, fish remains come mainly from Northern pike (Esox lucius) and European eel (Anguilla anguilla), as well as European perch (Perca fluviatilis) and cyprinids (Cyprinidae) (Marinval-Vigne et al. 1989; Ducrocq 2014). The fluviatile environment is dominated by peat deposit, and the aquatic ecosystem is highly influenced by terrestrial input and shows relatively low productivity. We thus used the 
Table 1 List of the studied archaeological sites from northern France with number of human and animal specimens directly dated. * samples more specifically identified as aurochs

\begin{tabular}{|c|c|c|c|c|c|c|c|c|c|c|}
\hline Town & Locality & District & Culture & $\mathrm{N}^{\circ}$ lab & Human & $\begin{array}{l}\text { Red } \\
\text { deer }\end{array}$ & $\begin{array}{l}\text { Wild } \\
\text { boar }\end{array}$ & $\begin{array}{l}\text { Roe } \\
\text { deer }\end{array}$ & $\begin{array}{l}\text { Large } \\
\text { bovid }\end{array}$ & Elk \\
\hline La Chaussée-Tirancourt & Le Petit Marais & Somme & Mesolithic & CTpm- & 1 & 5 & & & & \\
\hline Belloy-sur-Somme & La Plaisance & Somme & Mesolithic & BEL- & & 1 & & & $2 *$ & \\
\hline Saleux & La Vierge Catherine & Somme & $\begin{array}{l}\text { Federmesser \& } \\
\text { Mesolithic }\end{array}$ & SA- & & 1 & & 1 & & \\
\hline Hangest-sur-Somme & Gravière I/II nord & Somme & Mesolithic & HI-/HII- & & 2 & & & & \\
\hline Conty & Le Marais & Somme & $\begin{array}{l}\text { Federmesser \& } \\
\text { Mesolithic }\end{array}$ & CTY- & & 2 & & & & \\
\hline Blangy-Tronville & La Petite Tête & Somme & Mesolithic & BLA- & & & 1 & & & \\
\hline Pont-de-Metz & Rue du Petit Saint-Jean & Somme & Mesolithic & PMZ & & & & & 1 & \\
\hline Warluis & Merlemont & Oise & Mesolithic & WRL- & & 2 & 3 & 2 & & 1 \\
\hline Val-de-Reuil & Les Varennes & Eure & Mesolithic & VAL- & 2 & & & & & \\
\hline Paris & 62 rue Henry-Farman & Paris & Mesolithic & PHF- & & & 2 & & $1 *$ & \\
\hline
\end{tabular}

Mesolithic river fishes from Abri du Pape in Belgium (Drucker et al. 2018) and Friesack 4 in northern Germany (Meadows et al. 2018; Robson pers. comm. 2019) as proxies for the freshwater resources, since they correspond to the same Preboreal to Boreal chronology and aquatic environment (same fish species and ecological productivity) as for our studied context.

We investigated two human individuals from Val-de-Reuil "Les Varennes" and one from La Chaussée-Tirancourt "Le Petit Marais" (Fig. 1). The two individuals of Val-de-Reuil were excavated from two separate levels of the same burial pit. One (sujet A, sample 2050, VLR-1), a male adult, was found with its skeleton in articulation in context of a primary deposit (Billard et al. 2001). A second individual (sujet B, sample 2010, VLR-2) along with a third individual (sujet C) were present in the pit as scattered bones, resulting from previous inhumations manipulations. Sujet B (sample 2010, VLR-2) was also a mature adult, probably a man, while sujet $C$ was a young adult or an adolescent of unidentified sex. Sujet $\mathrm{B}$ and sujet $\mathrm{C}$ were previously buried before their bones were

Fig. 1 Geographical location of the archaeological sites with faunal and human remains analyzed for this work

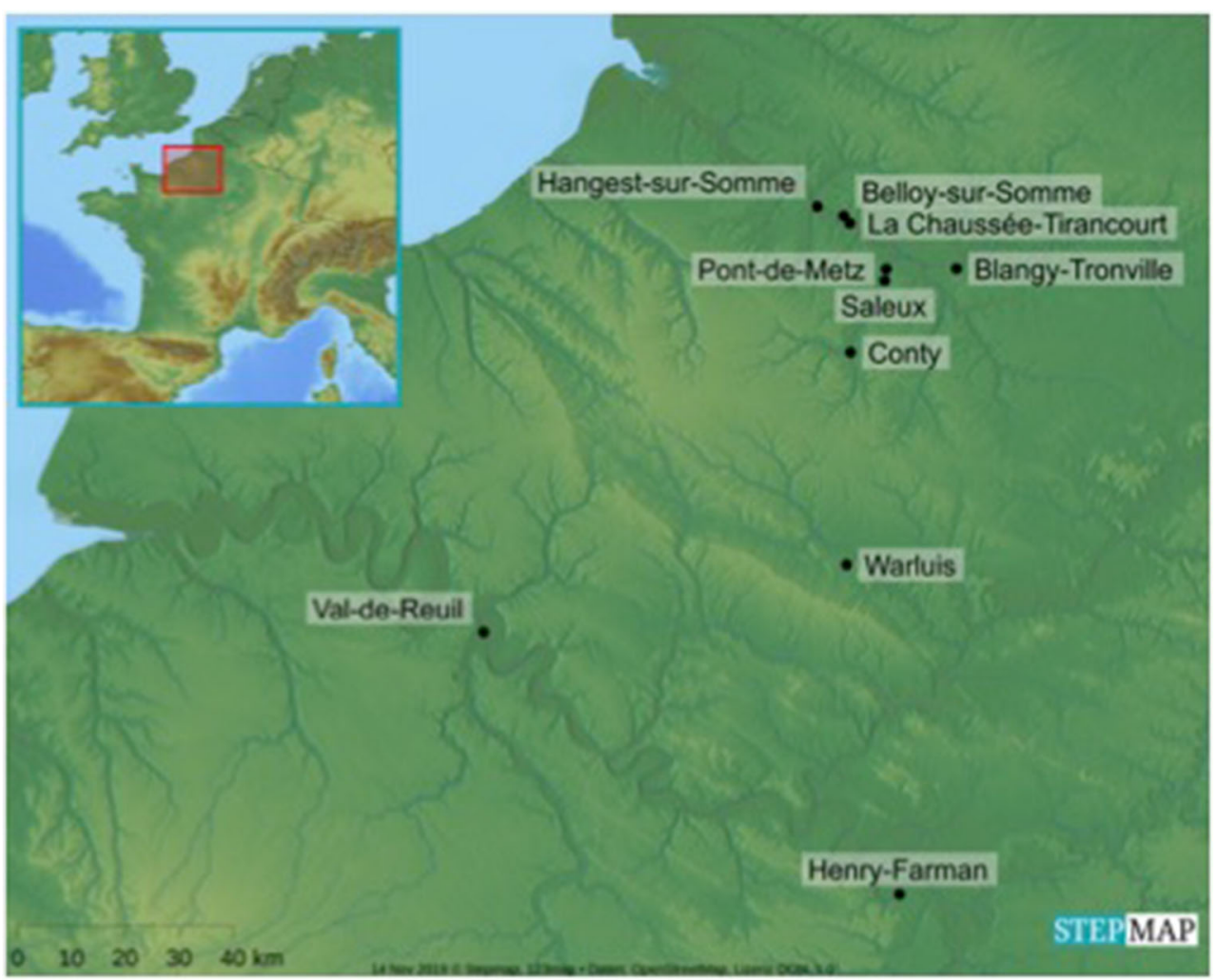


re-arranged to allow some space for the deposition of sujet A. A first dating attempt was conducted on a set of long bones from sujet A (8715 \pm 310 BP Ly-6239; Billard et al. 2001). We present here the results of a new AMS radiocarbon dating on this individual and of sujet B. At La Chaussée-Tirancourt, the selected human corresponds to a male adult aged between 50 and 60 years old (Valentin 1995; Ducrocq et al. 1996) whose almost complete skeleton was deposited in a small pit (F4 structure) after some manipulation that resulted in a compact and sorted pile of the bones following a secondary burial process (Ducrocq et al. 1996). The individual was dated to $9020 \pm 100$ BP (GifA-95523) before a second AMS radiocarbon result of $9240 \pm 45 \mathrm{BP}$ was obtained from the same femur (SacA-23956; Ducrocq 2017).

At both Val-de-Reuil and La Chaussée-Tirancourt, animal remains were excavated. The faunal specimens at Val-deReuil were subjected to fire, and none of the attempts to retrieve collagen was successful due to destruction of the organic matter. At La Chaussée-Tirancourt, the animal bones were systematically dated to a later chronological phase, mainly Boreal, than the individual from structure F4 (Ducrocq 2017 , this work). Thus, we could not retain the faunal remains coming directly from the sites to document the isotopic baseline for the human diet reconstruction.

Collagen extraction was conducted at the Department of Geosciences of Tübingen University following the protocol of Longin (1971) as modified by Bocherens et al. (1997). In brief, the extraction procedure includes a step of demineralization in $\mathrm{HCl} 1 \mathrm{M}$, a step of soaking in $0.125 \mathrm{M} \mathrm{NaOH}$, and a final step of solubilization in acidified water $(\mathrm{pH}=2)$ before the freeze-drying process. The elemental analyses $(\mathrm{C}, \mathrm{N})$ and isotopic measurements $\left(\delta^{13} \mathrm{C}, \delta^{15} \mathrm{~N}\right)$ were performed at the Institut des Sciences de l'Evolution of Montpellier 2 University in France on a CHN-elemental analyzer (Eurovector) coupled to a VG-Optima continuous-flow ratio mass spectrometer for one set of faunal specimens (WRL-1, CTpm-1 to CTpm-9, BEL-1, CTY2, SA-1, HI-1), and at the geochemical unit of the Geoscience Faculty at the University of Tübingen (Germany) using an elemental analyzer NC 2500 connected to a ThermoQuest Delta+XL mass spectrometer for the human individuals and another set of animal samples (WRL-6 to WRL-19, CTpm-10 to CTpm-17, BEL-3 and BEL-4, CTY4, SA-2, HII-2, PMZ-1, BLA-1). The isotopic ratios are expressed using the " $\delta$ " (delta) value as follows: $\delta^{13} \mathrm{C}=\left[\left({ }^{13} \mathrm{C} /{ }^{12} \mathrm{C}\right)_{\text {sample }} /\left({ }^{13} \mathrm{C} /{ }^{12} \mathrm{C}\right)_{\text {standard }}{ }^{-1} \times \times 1000 \%\right.$ and $\delta^{15} \mathrm{~N}=\left[\left({ }^{15} \mathrm{~N} /{ }^{14} \mathrm{~N}\right)_{\text {sample }} /\left({ }^{15} \mathrm{~N} /{ }^{14} \mathrm{~N}\right)_{\text {standard }}{ }^{-1}\right] \times 1000 \%$. The measurements were calibrated in reference to the international standards (V-PDB for carbon and AIR for nitrogen) using cane sucrose $\left(\delta^{13} \mathrm{C}=-11.0 \%\right.$ ) and urea $\left(\delta^{15} \mathrm{~N}=-0.33 \%\right.$ ) USGS-24 $\left(\delta^{13} \mathrm{C}=-16.0 \%\right.$ ) , IAEA 305A $\left(\delta^{15} \mathrm{~N}=+39.8 \%\right.$ ) , and in-house reference materials (modern collagen of camel and elk). Analytical precision, based on within-run replicate measurements of laboratory standards (egg albumin, keratin, alanine amino acid, modern collagen), was $\pm 0.1 \%$ ofor $\delta^{13} \mathrm{C}$ and $\pm 0.2 \%$ o for $\delta^{15} \mathrm{~N}$. The biochemical reliability of the collagen was estimated by considering the chemical composition, with $\mathrm{C} / \mathrm{N}$ atomic ratio $(\mathrm{C}: \mathrm{N})$ ranging from 2.9 to 3.6 (DeNiro 1985) and percentages of $\mathrm{C}$ and $\mathrm{N}$ above $8 \%$ and 3\%, respectively (Ambrose 1990). For radiocarbon dating, a C content equal or above $30 \%$ is recommended (van Klinken 1999).

Elemental and isotopic analysis of sulfur ( $\mathrm{S}$ and $\delta^{34} \mathrm{~S}$ ) were conducted at the Department of Geosciences of Tübingen University using a NC2500 CHN-elemental analyzer coupled to a ThermoQuest Delta + XL mass spectrometer. Samples were calibrated to $\delta^{34} \mathrm{~S}$ values relative to V-CDT using NBS $123\left(\delta^{34} \mathrm{~S}=17.1 \%\right)$, NBS $127\left(\delta^{34} \mathrm{~S}=20.3 \%\right)$, IAEA-S-1 $\left(\delta^{34} \mathrm{~S}=-0.3 \%\right.$ ) , and IAEA-S-3 $\left(\delta^{34} \mathrm{~S}=-32.3 \% \circ\right)$. The reproducibility is $\pm 0.4 \%$ for $\delta^{34} \mathrm{~S}$ measurements, and the error on $\mathrm{S}$ measurement is $5 \%$. We retained $\delta^{34} \mathrm{~S}$ values of samples whose atomic $\mathrm{C}: \mathrm{S}$ and $\mathrm{N}: \mathrm{S}$ fit into the range of 300-900 and 100-300, respectively (Nehlich and Richards 2009), and whose percentage of S ranged from 0.14 to $0.26 \%$, as provided by modern mammalian collagen (Aldrich collagen, modern elk and modern camel) measured in the same sets. In the case of fish remains, the preservation criteria are different with $\mathrm{C}: \mathrm{S}$ and $\mathrm{N}: \mathrm{S}(\mathrm{C} / \mathrm{S}$ and $\mathrm{N} / \mathrm{S}$ atomic ratios) that should fit into the range of 125-225 and 40-80, respectively, since their S content is higher than in mammalian collagen (ca. 0.40 to $0.85 \%$ ) (Nehlich and Richards 2009).

To group the dietary resources in this study, we applied a multivariate cluster analysis to the $\delta^{13} \mathrm{C}$ and $\delta^{15} \mathrm{~N}$ isotopic values, using the Ward's minimum variance method in JMP 14. This method is quite common for group formation in paleoecological stable isotope research (e.g., Bocherens et al. 2015; Wißing et al. 2019; Baumann et al. 2020). As a result, we obtained three different clusters of terrestrial resources and one of freshwater resources. We used the R package SIBER (Stable Isotope Bayesian Ellipses in R) following the protocol of Jackson et al. (2011) to check that the niches of the calculated diet resource groups do not overlap. On the one hand, we calculated the complete niche (convex hull; Layman et al. 2007) that includes all specimens of a source group and, on the other hand, we calculated the standard ellipse area (SEA) by using a most likelihood estimation. SEA explains $40 \%$ of the data and is recommended by Jackson et al. (2011) to decipher the core niche, which is still informative even with smaller sample sizes.

We simulated the possible proportions of different prey group in the protein fraction of the human diet using MixSIAR (Bayesian Mixing Models in R, Stock and Semmens 2016). The calculations of this package are based on a Bayesian statistical approach, which is quite robust for small sample sizes $(n<20)$ (Inger et al. 2010). To get a robust statistical analysis, we set the MCMC (Markov Chain Monte Carlo, see Stock and Semmens (2016) chain length to $1,000,000$ with a burn-in of 500,000 in 3 chains. We verified 
the model convergence with Gelman-Rubin and Geweke tests. The Gelman-Rubin test shows model convergence if the values are near 1. In most analyses, values below 1.1 are acceptable (Gelman et al. 2014). Additionally, the Geweke test compares the mean of the first part of each chain with the mean of the second part, using a two-sided z-test. If both means are the same, the model is convergent (Stock and Semmens 2016). MixSIAR allowed us to reconstruct the most likely diet of the different human individuals based on the bone collagen $\delta^{13} \mathrm{C}$ and $\delta^{15} \mathrm{~N}$ values. The stable carbon and nitrogen isotope composition of a consumer is enriched from those of its prey in a predictable manner (e.g., Bocherens and Drucker 2003). Here, TEF values reflect the enrichment in ${ }^{13} \mathrm{C}$ and ${ }^{15} \mathrm{~N}$ abundances in the collagen of the consumer compared with those of the collagen of the preys. For this study, we applied TEF of $+1.1 \pm 0.2 \%$ and $+3.8 \pm 1.1 \%$ o for $\delta^{13} \mathrm{C}$ and $\delta^{15} \mathrm{~N}$ values, respectively, as published in Bocherens et al. (2015).

\section{Results and discussion}

\section{$\delta^{13} \mathrm{C}$ and $\delta^{15} \mathrm{~N}$ values of the red deer over time in northern France}

The $\delta^{13} \mathrm{C}$ and $\delta^{15} \mathrm{~N}$ values of the bone collagen of the red deer ranged from $-23.7 \%$ to $-20.5 \%$ and from +2.8 to $+6.4 \%$, respectively, during the early Holocene (Table 2). No specimens could be attributed to the last cold spell before the general warming of the Holocene, the so-called Younger Dryas or GS-1, leading to a gap in the chronological isotopic record (Table 2, Fig. 2), a situation that we also experienced with the red deer of the French Jura and western Alps (Drucker et al. 2011). A hiatus in the archaeological record in northern France is indeed demonstrated during this period and could reflect a lack of human occupation in the context of intensified flow frequency (Antoine et al. 2015).

The $\delta^{13} \mathrm{C}$ values of the red deer could be separated in two non-overlapping groups between the Late Glacial and Preboreal on the one hand $(-21.0 \%$ to $-20.5 \%$ ) and the successive Boreal and early Atlantic periods on the other hand ( $-23.7 \%$ o to $-22.5 \%$; Fig. 2). The significantly lower values of the Boreal and early Atlantic most likely corresponded to a change of habitat from open or lightly forested landscape to closed and densely forested habitat (Drucker et al. 2008, 2011). Palynological studies indeed point to such a closure effect of the landscape, with an increase of tree formations dominated by pine (Pinus) and birch (Betula) during the Preboreal. These boreal-like landscapes were gradually replaced by temperate forests dominated by hazel trees (Corylus) over the Preboreal to Boreal transition (Pastre et al. 2003; Coutard et al. 2010; Antoine et al. 2014). The malacological record evidences the increase of thermophilous species over the early Holocene, especially those associated with the dense forest which expanded at the end of the Preboreal (Coutard et al. 2010; Antoine et al. 2014). A change from deer and aurochs to wild boar predation is illustrated at Warluis over the Preboreal to Boreal transition (Coutard et al. 2010). The change in the atmospheric $\delta^{13} \mathrm{C}$ values of ca. + $0.3 \%$ o (Schmitt et al. 2012), at the Late Glacial to early Holocene transition, could not account for the decrease of more than $2 \%$ observed in the red deer collagen. A possible impact of the change in atmospheric $\mathrm{CO}_{2}$ concentration on the $\delta^{13} \mathrm{C}$ values of plants is still highly debated (e.g., Kohn 2016). Even in the case of atmospheric $\mathrm{CO}_{2}$ concentration dependence, namely, lower plant $\delta^{13} \mathrm{C}$ values due to increasing $\mathrm{CO}_{2}$ concentration, we should observe decreasing $\delta^{13} \mathrm{C}$ values between ca. 11,000 and 13,000 cal BP when the atmospheric $\mathrm{CO}_{2}$ increased about $40 \mathrm{ppm}$ (Schmitt et al. 2012). However, such a pattern appears clearly after that time in our studied red deer. We thus interpret the decrease in $\delta^{13} \mathrm{C}$ values of the red deer as a shift to more closed dense habitat.

The pattern of ${ }^{13} \mathrm{C}$ variation in the red deer from northern France fits the one observed in the French Jura. In contrast, in the western Alps and the southern North Sea, also called Doggerland (Van der Plicht et al. 2016), red deer gave $\delta^{13} \mathrm{C}$ values equal or above $-22.5 \%$ over the early Holocene (Fig. 2). In both cases, the red deer seemed to have persisted in an open habitat, either through a move to higher altitude for the specimens in the Alps (Drucker et al. 2011) or a lack of a dense canopy in the territories of the specimen of the southern North Sea. Ecological studies of offshore locations along the south coast of England showed the occurrence of mixed woodland dominated by pine (Pinus) and hazel (Corylus) during the early Holocene (Gearey et al. 2017). The pollen record of two cores drilled in the center of the North Sea revealed an open birch (Betula) forest that included pine trees during the Preboreal, followed by a large expansion of hazel, replacing birch, at the onset of the Boreal (Krüger et al. 2017). Then, during the course of the Boreal, pine tree occurrence increased and became dominant over the deciduous woodland of oak (Quercus) and elm (Ulmus) formations (Krüger et al. 2017). The pine-dominated vegetation during the Boreal in the Doggerland differs from the hazel-dominated forest over the same period in eastern France (e.g., De Beaulieu et al. 1994) and northern France (e.g., Antoine et al. 2000; Coutard et al. 2010). This forest composition difference and the possibly higher frequency of open patches in the Doggerland could explain the relatively higher $\delta^{13} \mathrm{C}$ values of the red deer after the Preboreal.

The $\delta^{15} \mathrm{~N}$ values of the red deer from northern France showed an increasing tendency over the Late-Glacial and early Holocene (Fig. 3). The unique specimen dated to the Late Glacial interstadial (GI-1e to GI-1a) displayed the lowest $\delta^{15} \mathrm{~N}$ of all $(+2.8 \%$ ) , while one specimen of the Boreal provided the highest value $\left(+6.4 \%\right.$ ) . Like for the $\delta^{13} \mathrm{C}$ values, the 
㲅

는

过

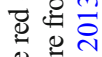

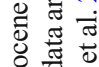

웅

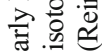

言

西 $=$

언

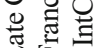

낭

政觉

일

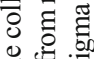

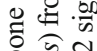

的旅

पू

할

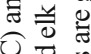

记

을

है न्षु

要这

막

人ิ

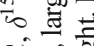

U.

过

.

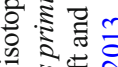

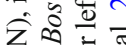

U

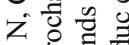

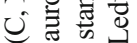

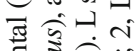

跣

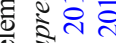

(ब)

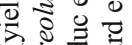

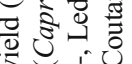

部密-

政

ช०

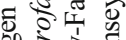

管

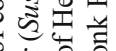

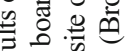

$\approx$ 证

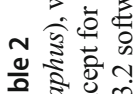

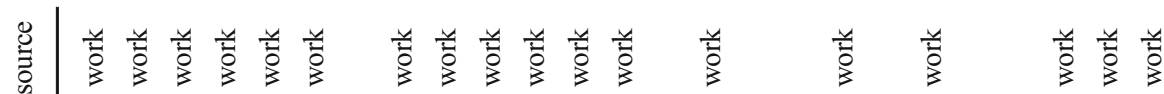

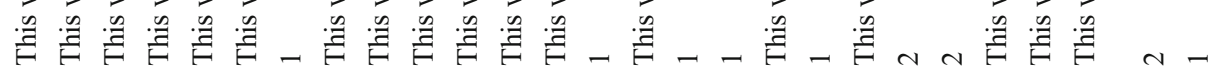

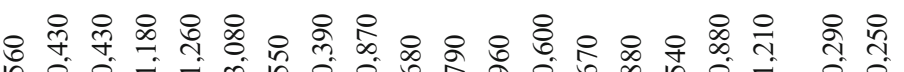

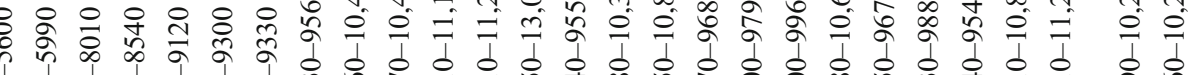

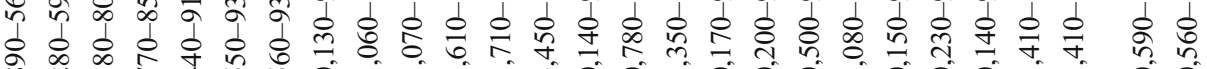

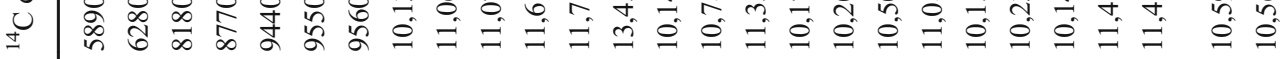

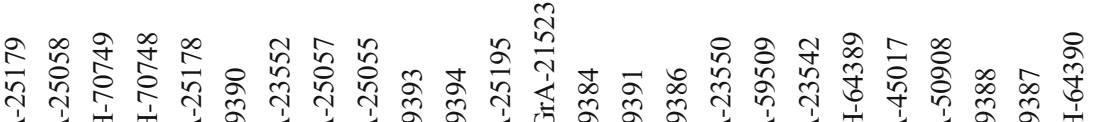

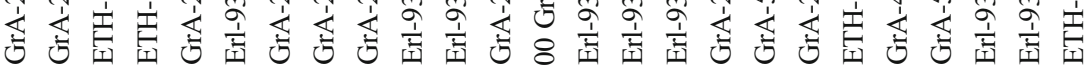

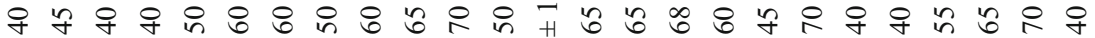

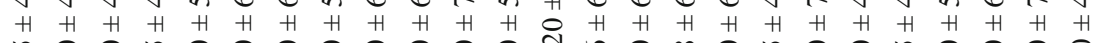

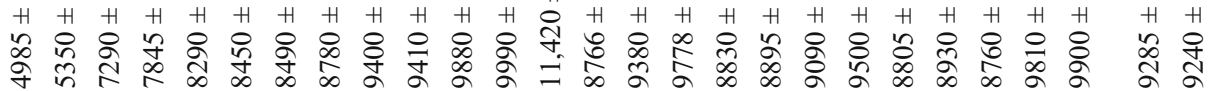

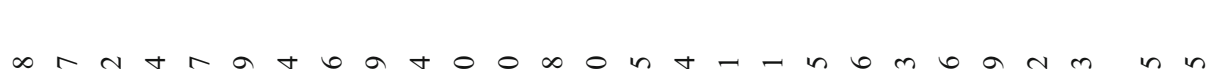

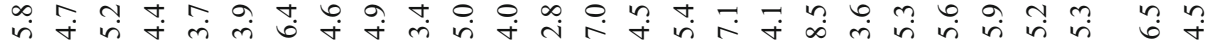

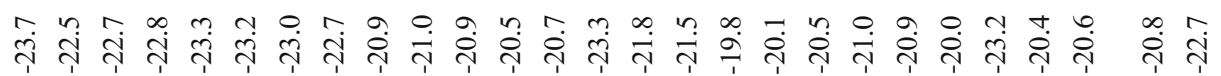

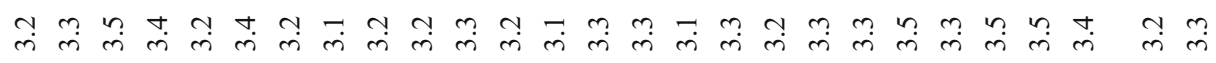

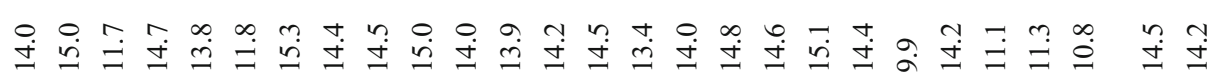

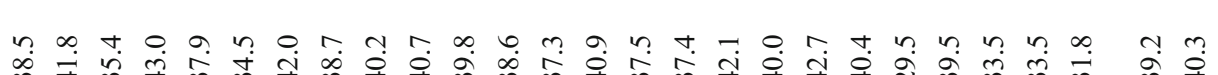

0

$\frac{8}{8}$

西

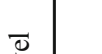

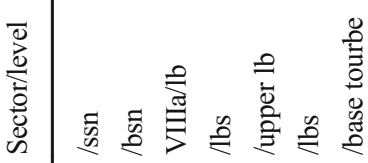

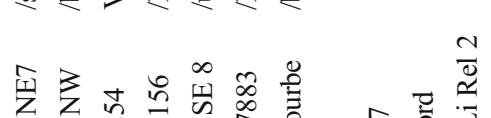

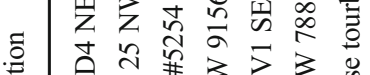

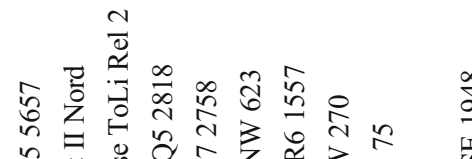

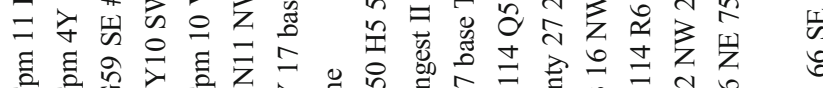

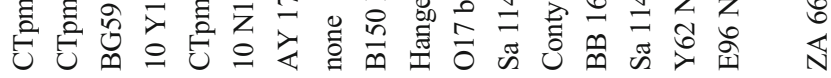

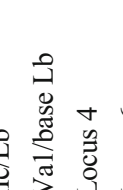

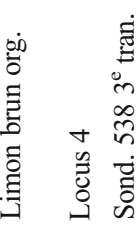

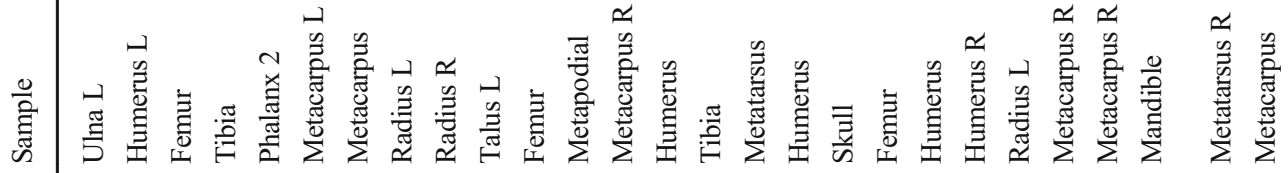

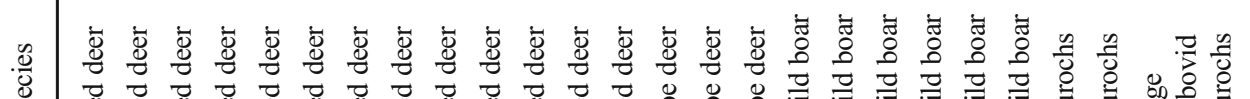

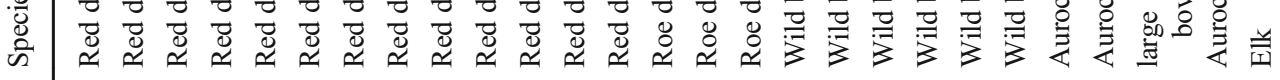

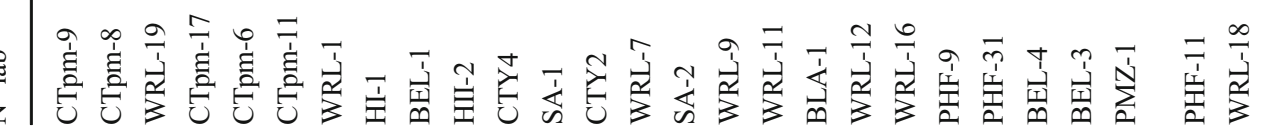


Fig. $2 \delta^{13} \mathrm{C}$ values of bone collagen of red deer (Cervus elaphus) from northern France (this work), French Jura (Drucker et al. 2011), western Alps (Drucker et al. 2011), and southern North Sea (van der Plicht et al. 2016) over time during the Late Glacial and early Holocene

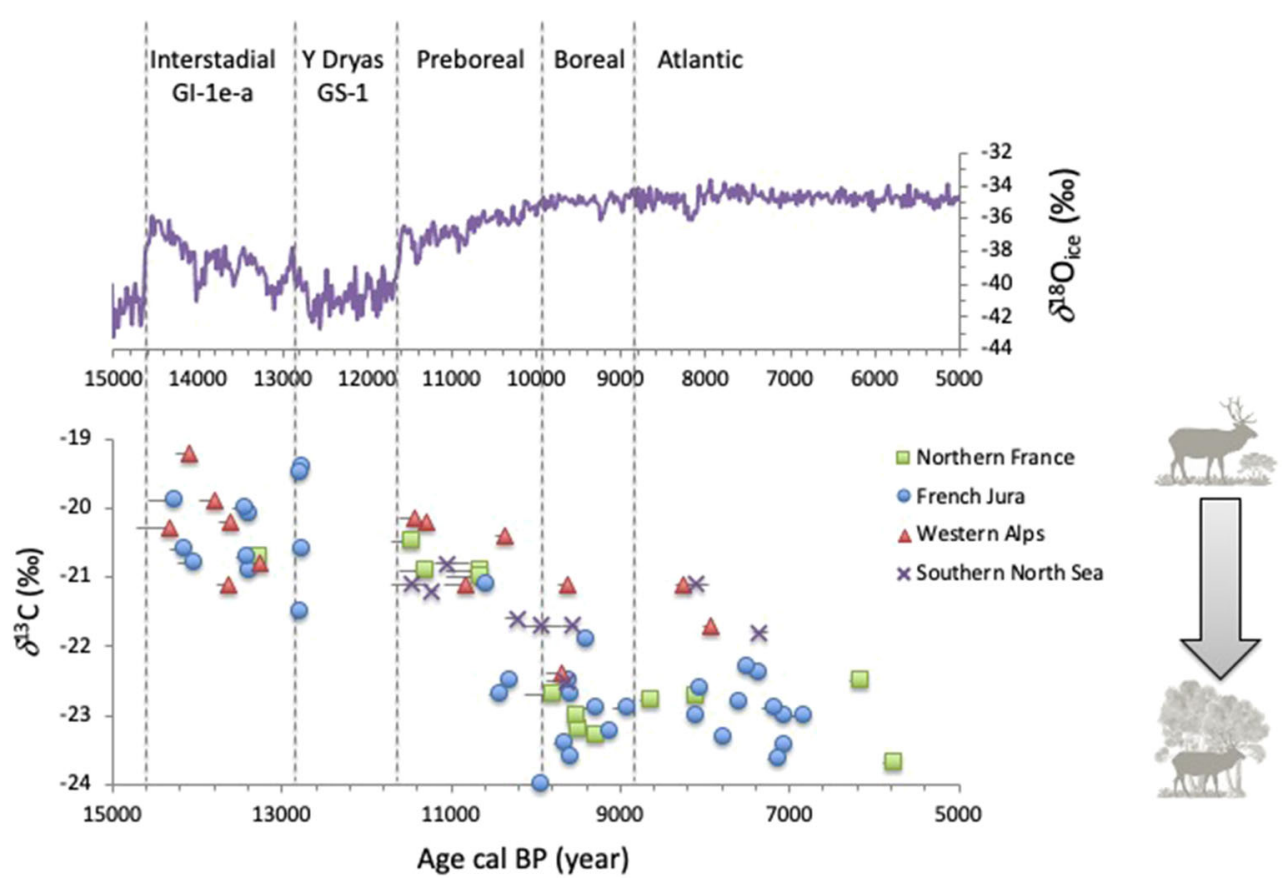

pattern of variation for $\delta^{15} \mathrm{~N}$ values of the red deer from northern France was more comparable with the one found for the red deer in the French Jura than in the western Alps or southern North Sea. Especially during the early Holocene, the red deer from northern France showed equivalent values to those of the French Jura, both being higher than those of the red deer from the western Alps. The increase in $\delta^{15} \mathrm{~N}$ values of this herbivore could indirectly reflect the rise in temperature through the intensification of soil activities, which can lead to an increase in the $\delta^{15} \mathrm{~N}$ values of plants (e.g., Hobbie et al. 2005; Drucker et al. 2011). In a warming context, microbial soil activity and thus $\mathrm{N}$ mineralization rates are enhanced leading to higher $\mathrm{N}$ supply to plants, which is reflected by higher $\delta^{15} \mathrm{~N}$ values in foliage (Craine et al. 2009, 2015). A shift to a higher altitude, as could take place in the mountainous regions such as the Jura and the Alps, would result in attenuating this effect, since the $\delta^{15} \mathrm{~N}$ values of soils and plants decrease when altitude increases, which thus may
Fig. $3 \delta^{15} \mathrm{~N}$ values of bone collagen of red deer (Cervus elaphus) from northern France (this work), French Jura (Drucker et al. 2011), western Alps (Drucker et al. 2011), and southern North Sea (van der Plicht et al. 2016) over time during the Late Glacial and early Holocene

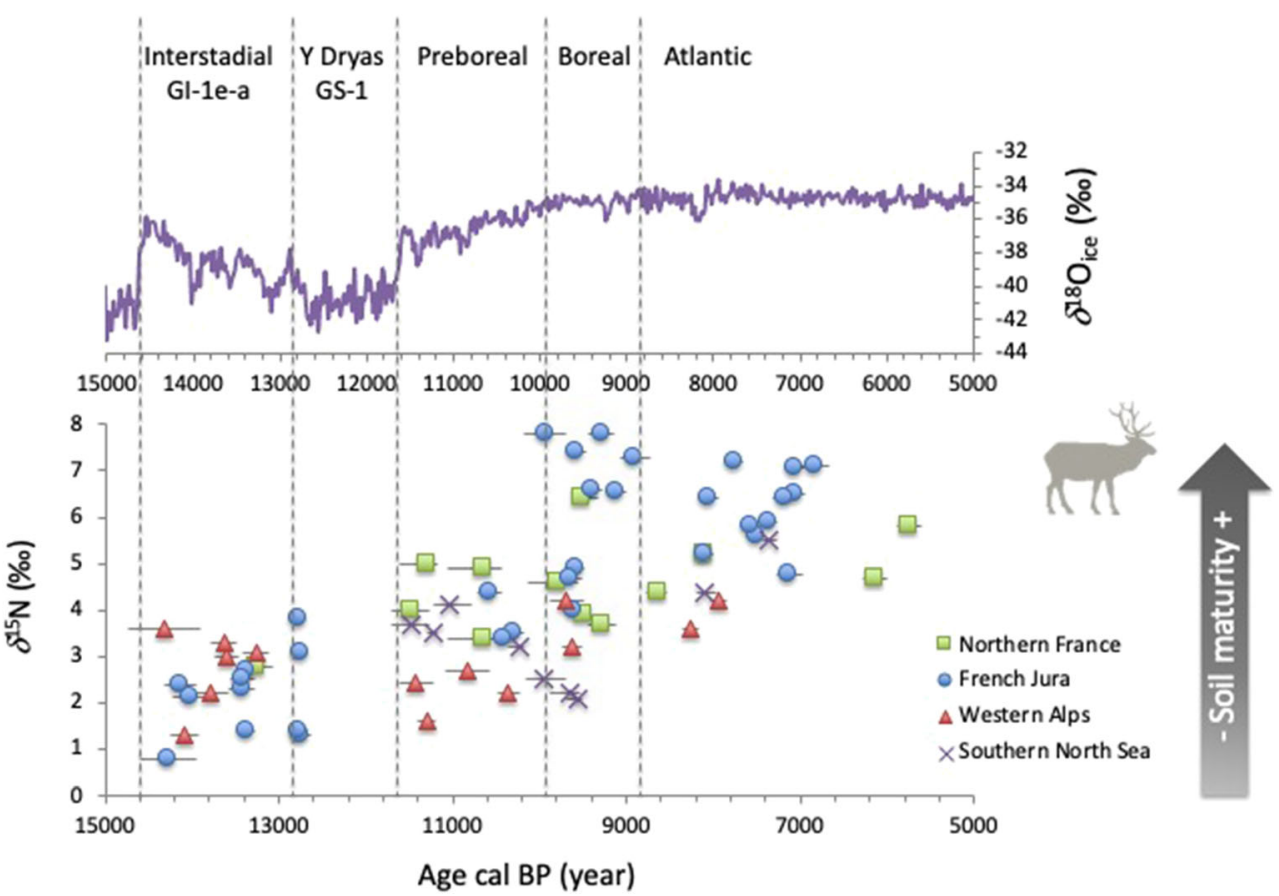


counterbalance the effect of global warming on $\delta^{15} \mathrm{~N}$ values (e.g., Männel et al. 2007; Drucker et al. 2011). The red deer for the North Sea provided a quite different pattern, with an apparent decrease in ${ }^{15} \mathrm{~N}$ abundances over the Preboreal and start of the Boreal. This could be due to an additional location effect, in other words a wider geographical origin than reflected by the location of the collection site of the bones. Since the North Sea specimens have been collected opportunistically from net fishing or sand dredging activities, their exact former location is unfortunately not possible to pinpoint (Van der Plicht et al. 2016). As a matter of fact, a large range of $\delta^{15} \mathrm{~N}$ values characterized the red deer specimens of French Jura and northern France during the Boreal, showing that higher ${ }^{15} \mathrm{~N}$ contrast according to location may be expected at that time. Nevertheless, higher red deer $\delta^{15} \mathrm{~N}$ values in the North Sea were finally found in the early Atlantic compared with the Preboreal and Boreal periods, as observed in the other regions. All in all, the observed contrasts in $\delta^{15} \mathrm{~N}$ values of red deer over time and space underline the importance of the isotopic investigation at a constrained spatial and chronological scale to most accurately reconstruct the trophic web.

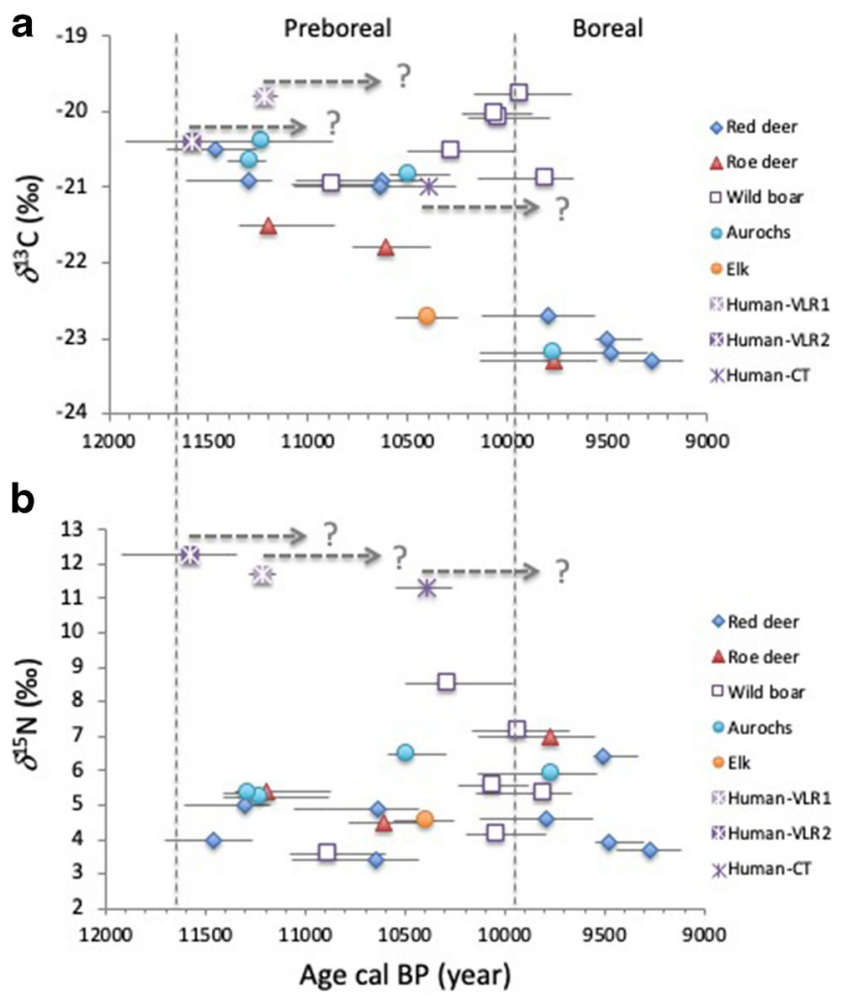

Fig. 4 Results of $\delta^{13} \mathrm{C}$ (a) and $\delta^{15} \mathrm{~N}$ (b) values on red deer (Cervus elaphus), roe deer (Capreolus capreolus), wild boar (Sus scrofa), Aurochs (Bos primigenius), elk (Alces alces), and human individuals from Val-de-Reuil (VLR) and La Chaussée-Tirancourt (CT) over time. The dotted arrows indicate possible reservoir effect on the radiocarbon dating of the human individuals.

\section{$\delta^{13} \mathrm{C}$ and $\delta^{15} \mathrm{~N}$ of large herbivore species during the early Holocene in northern France}

We considered not only red deer but also other species in northern France during the early Holocene (Table 2, Fig. 4). The wild boar $\delta^{13} \mathrm{C}$ and $\delta^{15} \mathrm{~N}$ values varied from $-21.0 \%$ to $19.8 \%$ and +3.6 to $+8.5 \%$, respectively. The roe deer and the aurochs displayed the comparable range of $\delta^{13} \mathrm{C}(-23.3 \%$ o to $-21.5 \%$ and -23.2 to $-20.4 \%$, respectively) and $\delta^{15} \mathrm{~N}$ values $(+4.5$ to $+7.0 \%$ and +5.2 to $+6.5 \%$, respectively). We observed a difference in the variation pattern according to species: a decrease in $\delta^{13} \mathrm{C}$ values for the aurochs and roe deer that appeared quite similar to the pattern provided by the red deer. The wild boar, in contrast, showed no $\delta^{13} \mathrm{C}$ values below $-21 \%$, likely because their feeding habits prevent them to reflect any canopy effect (consumption of fruits and underground tubers; Schley and Roper 2003; Baubet et al. 2004). This difference in the $\delta^{13} \mathrm{C}$ chronological tendencies between wild boar and other species or for the same species, such as the red deer, between different geographical locations implies a local effect in contrast to the result of a global change in carbon isotopic composition and/or concentration in the atmosphere (see also Drucker et al. 2008). The $\delta^{15} \mathrm{~N}$ values of the large herbivores did not reveal a spectacular change throughout the Preboreal period. However, the highest $\delta^{15} \mathrm{~N}$ values of the wild boar appeared by the end of the Preboreal. This pattern appears consistent with the rising ${ }^{15} \mathrm{~N}$ abundances in soils and plants triggered by increasing temperature through enhanced N-cycling by microorganisms (Craine et al. 2009; Hobbie and Högberg 2012). Finally, the elk specimen dated to the end of the Preboreal gave a $\delta^{13} \mathrm{C}$ value of $-22.7 \%$, which pointed to a more closed habitat than for the coeval red deer, while the elk $\delta^{15} \mathrm{~N}$ value of $+4.5 \%$ was in line with those of the other deer species. Thus, the Preboreal appears as a key period of change toward more forested habitat for the deer species in a context of increasing soil productivity.

\section{$\delta^{13} \mathrm{C}, \delta^{15} \mathrm{~N}$, and $\delta^{34} \mathrm{~S}$ values of the human individuals over the Preboreal}

The human individuals were all directly dated and the results are reported in Table 3. The results pointed to a Preboreal age during which early Mesolithic culture developed. A possible consumption of aquatic food items could lead to a reservoir effect. As a result, the human individuals' chronological ages could be in fact younger, to up to several hundred years, than the apparent age given by the ${ }^{14} \mathrm{C}$ results, as found in Mesolithic contexts by Meadows et al. (2018) and Boethius et al. (2017). A review by Fernandes et al. (2016) showed a reservoir effect that accounted for a shift of up to 500 years older in radiocarbon ages for Mesolithic and Neolithic human individuals in Europe. Thus, the chronological difference between the two individuals from Val-de-Reuil may 
Table 3 Results of collagen extraction yield (yield), elemental (C, N, $\mathrm{C}: \mathrm{N})$, isotopic $\left(\delta^{13} \mathrm{C}, \delta^{15} \mathrm{~N}\right)$, and radiocarbon $\left({ }^{14} \mathrm{C}\right)$ analyses on human individuals from Val-de-Reuil and La Chaussée-Tirancourt. L stands for left and $\mathrm{R}$ for right. Radiocarbon calibrations are given with 2 sigma based on IntCal13 dataset (Reimer et al. 2013) and OxCal 4.3.2 software (Bronk Ramsey 2017)

\begin{tabular}{llllllllllll}
\hline $\mathrm{N}^{\circ}$ lab & Sample & $\mathrm{N}^{\circ}$ excavation & Yield $(\%)$ & $\mathrm{C}(\%)$ & $\mathrm{N}(\%)$ & $\mathrm{C}: \mathrm{N}$ & $\delta^{13} \mathrm{C}(\%)$ & $\delta^{15} \mathrm{~N}(\%)$ & ${ }^{14} \mathrm{C}$ date BP & ${ }^{14} \mathrm{C}$ date cal BP & ${ }^{14} \mathrm{C}$ source \\
\hline VLR-1 & Ulna L & Sujet A 2050 & 8.6 & 43.2 & 15.1 & 3.3 & -19.8 & 11.7 & $9800 \pm 45$ GrA-40464 & $11,280-11,150$ & This work \\
VLR-2 & Ulna R & Sujet B 2010 & 4.9 & 42.8 & 15.3 & 3.3 & -20.4 & 12.3 & $10,065 \pm 45$ GrA-40483 & $11,920-11,340$ & This work \\
CTpm-12 & Femur L & Ila lb F4 6075 & 3.1 & 42.7 & 13.8 & 3.6 & -21.0 & 11.3 & $9240 \pm 45$ SacA-23956 & $10,550-10,260$ & Ducrocq 2017 \\
\hline
\end{tabular}

overestimate the time span between the burial depositions in the case of a difference in diet, namely, in the intake of aquatic resources. The ca. 360 years of difference between the calibrated dates of the two individuals from Val-de-Reuil would indeed imply that the memory of the exact location of the burial could be maintained over several centuries. Alternatively, it could point to a dietary reservoir effect generated by the consumption of aquatic resources, which would have been stronger for the individual VLR-2 (sujet B) than for the individual VLR-1 (sujet A).

To reconstruct the trophic baseline, we selected not only the fauna from the Preboreal period but also fauna dated to the transition to the Boreal in order to account for the potential chronological uncertainty of the human ${ }^{14} \mathrm{C}$ ages (Table 4, Fig. 5, and Fig. SD1). The $\delta^{13} \mathrm{C}$ values of the Val-de-Reuil individuals, VLR-1 and VLR-2, were $-19.8 \%$ and $-20.4 \%$,
Table 4 Results of collagen extraction yield (yield), elemental (C, N, $\mathrm{C}: \mathrm{N}, \mathrm{C}: \mathrm{S}, \mathrm{N}: \mathrm{S})$, and isotopic $\left(\delta^{13} \mathrm{C}, \delta^{15} \mathrm{~N}, \delta^{34} \mathrm{~S}\right)$ analyses on fauna selected for the comparison with human individuals from Val-de-Reuil and $\mathrm{La}$
Chaussée-Tirancourt. All isotope data are from this work, except $\delta^{13} \mathrm{C}$ and $\delta^{15} \mathrm{~N}$ values of specimens from the site of Henry-Farman (PHF-, Leduc et al. 2013). L stands for left and $\mathrm{R}$ for right

\begin{tabular}{|c|c|c|c|c|c|c|c|c|c|c|c|c|c|}
\hline $\mathrm{N}^{\circ}$ lab & Species & Sample & $\mathrm{N}^{\circ}$ excavation & Yield (\%) & $\mathrm{C}(\%)$ & $\mathrm{N}(\%)$ & $\mathrm{C}: \mathrm{N}$ & $\delta^{13} \mathrm{C}(\% o)$ & $\delta^{15} \mathrm{~N}(\% \circ)$ & $\mathrm{S}(\%)$ & $\delta^{34} \mathrm{~S}(\% o)$ & $\mathrm{C}: \mathrm{S}$ & $\mathrm{N}: \mathrm{S}$ \\
\hline & & & & & & $(\%)$ & & & & & & & \\
\hline CTpm-12 & Human & Femur L & Iia lb F4 6075 & 3.1 & 42.7 & 13.8 & 3.6 & -21.0 & 11.3 & 0.20 & 7.8 & 569 & 158 \\
\hline VLR-1 & Human & Ulna L & sujet A 2050 & 8.6 & 43.2 & 15.1 & 3.3 & -19.8 & 11.7 & 0.16 & 8.7 & 736 & 220 \\
\hline VLR-2 & Human & Ulna R & sujet B 2010 & 4.9 & 42.8 & 15.3 & 3.3 & -20.4 & 12.3 & 0.17 & 6.9 & 659 & 202 \\
\hline PHF-24 & Red deer & Radius R & $\begin{array}{c}1 / 4 \text { A iso } 2319 \\
166 / 971\end{array}$ & 1.3 & 36.4 & 12.9 & 3.3 & -20.1 & 4.3 & & & & \\
\hline HI-1 & Red deer & Radius L & none & 3.8 & 38.7 & 14.4 & 3.1 & -22.7 & 4.6 & & & & \\
\hline HII-2 & Red deer & Talus L & none & 8.0 & 40.7 & 15.0 & 3.2 & -21.0 & 3.4 & 0.14 & 6.8 & 754 & 238 \\
\hline BEL-1 & Red deer & Radius R & B150 H5 5657 & 1.1 & 40.2 & 14.5 & 3.2 & -20.9 & 4.9 & & & & \\
\hline SA-1 & Red deer & Metacarpus & $\begin{array}{l}\text { Sa 114 Q5 } 2818 \\
\text { LGVG }\end{array}$ & 3.1 & 38.6 & 13.9 & 3.2 & -20.5 & 4.0 & 0.16 & 6.8 & 631 & 195 \\
\hline CTY4 & Red deer & Femur & $\begin{array}{l}\text { Conty } \mathrm{O} 17 \text { base } \\
\text { ToLi Rel } 2\end{array}$ & 5.8 & 39.8 & 14.0 & 3.3 & -20.9 & 5.0 & 0.18 & 8.5 & 586 & 177 \\
\hline PHF-22 & Wild boar & Humerus R & B $165 / 964 n^{\circ} 14$ & 1.3 & 30.9 & 10.6 & 3.4 & -19.8 & 8.3 & & & & \\
\hline PHF-9 & Wild boar & Humerus R & décap.sud iso822 & 1.4 & 29.5 & 9.9 & 3.5 & -20.9 & 5.3 & & & & \\
\hline PHF-10 & Wild boar & Humerus R & décap. sud iso876 & 1.9 & 35.1 & 12.2 & 3.4 & -20.1 & 5.9 & 0.16 & 10.3 & 600 & 179 \\
\hline PHF-31 & Wild boar & Radius L & est iso1291 & 1.4 & 39.5 & 14.2 & 3.3 & -20.0 & 5.6 & 0.18 & 9.5 & 595 & 183 \\
\hline WRL-11 & Wild boar & Humerus & E96 NE 75 & 3.8 & 42.1 & 14.8 & 3.3 & -19.8 & 7.1 & 0.19 & -0.8 & 596 & 180 \\
\hline WRL-12 & Wild boar & Femur & ZA 66 SE 1948 & 8.0 & 42.7 & 15.1 & 3.3 & -20.5 & 8.5 & 0.19 & 4.3 & 594 & 180 \\
\hline WRL-16 & Wild boar & Humerus & & 4.8 & 40.4 & 14.4 & 3.3 & -21.0 & 3.6 & 0.18 & -1.5 & 609 & 186 \\
\hline PHF-11 & Aurochs & Metatarsus R & décap. sud iso895 & 2.9 & 39.2 & 14.5 & 3.2 & -20.8 & 6.5 & 0.16 & 11.6 & 672 & 213 \\
\hline BEL-4 & Aurochs & Metacarpus R & В 150 E5 5119 & 3.4 & 33.5 & 11.1 & 3.5 & -23.2 & 5.9 & & & & \\
\hline BEL-3 & Aurochs & Metacarpus R & В 150 H6 5394 & 3.4 & 33.5 & 11.3 & 3.5 & -20.4 & 5.2 & 0.14 & 11.2 & 625 & 181 \\
\hline PMZ-1 & large bovid & Mandible & sondage $2 / 2$ bis & 1.8 & 31.8 & 10.8 & 3.4 & -20.6 & 5.3 & & & & \\
\hline WRL-7 & Roe deer & Humerus & BB 16 NW 623 & 2.7 & 40.9 & 14.5 & 3.3 & -23.3 & 7.0 & & & & \\
\hline SA-2 & Roe deer & Tibia & $\begin{array}{l}\text { Sa } 114 \text { R6 } 1557 \\
\text { sommet LGVG }\end{array}$ & 12.0 & 37.5 & 13.4 & 3.3 & -21.8 & 4.5 & 0.15 & 8.3 & 680 & 208 \\
\hline WRL-9 & Roe deer & Metatarsus & Y62 NW 270 & 3.8 & 37.4 & 14.0 & 3.1 & -21.5 & 5.4 & & & & \\
\hline WRL-18 & Elk & Metacarpus & & 6.1 & 40.3 & 14.2 & 3.3 & -22.7 & 4.5 & & & & \\
\hline
\end{tabular}




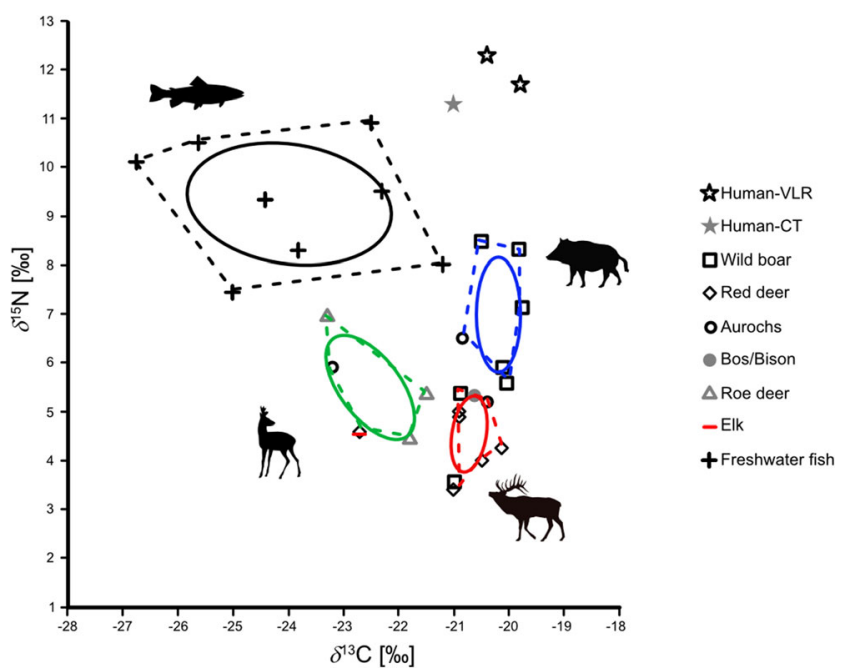

Fig. $5 \delta^{13} \mathrm{C}$ and $\delta^{15} \mathrm{~N}$ values of red deer (Cervus elaphus), roe deer (Capreolus capreolus), wild boar (Sus scrofa), Aurochs (Bos primigenius), elk (Alces alces) from the Preboreal and Preboreal/Boreal transition, and human individuals from Val-de-Reuil (VLR) and La Chaussée-Tirancourt (CT). Results of the diet resources calculated with SIBER (Jackson et al. 2011) are reported in dashed and solid line areas. Dashed line shows the convex hull, the smallest possible surface that encompasses all individuals of one group (Layman et al. 2007). Solid line shows the Bayesian-based Standard Ellipse Area (SEA), which reflects the core niche (Jackson et al. 2011) respectively, which corresponds to an average diet in terms of collagen value of ca. $-20.8 \%$ and $-21.4 \%$. This last range would correspond to the values observed in the open habitat deer and aurochs and/or some of the wild boar (Fig. 4a). With a $\delta^{13} \mathrm{C}$ value of $-21.0 \%$, the individual of La ChausséeTirancourt could reflect the consumption of forest-dwelling terrestrial preys (Fig. 4a). The $\delta^{15} \mathrm{~N}$ values of the humans from Val-de-Reuil were $+12.3 \%$ o for VLR-1 and $+11.7 \%$ o for VLR-2, which were more than $+5 \%$ higher than most of the Preboreal herbivores, except for two wild boars at the end of the Preboreal and start of the Boreal. These high ${ }^{15} \mathrm{~N}$ wild boars were 1000 years younger than the individuals of Val-de-Reuil in apparent calibrated age and indeed in line with the result of the warming effect over the Preboreal. The contribution of freshwater resources, with their higher $\delta^{15} \mathrm{~N}$ values $(+7.5$ to $+10.9 \%$; Table 5$)$ than the terrestrial fauna with an overlapping range of $\delta^{13} \mathrm{C}$ values $(-26.8 \%$ to $21.2 \%$; Table 5), is thus more likely. An aquatic contribution to the diet of the individual of La Chaussée-Tirancourt is more speculative since the high ${ }^{15} \mathrm{~N}$ wild boar and aurochs of the end of the Preboreal could account for the human $\delta^{15} \mathrm{~N}$ value of $+11.3 \%$. The freshwater resources were nevertheless tested for this individual as well in the application of the model calculations.

We applied ${ }^{34} \mathrm{~S}$ measurements on the human and fauna of northern France to explore a possible additional tracker of dietary resources (Tables 4 and 5). The $\delta^{34} \mathrm{~S}$ values of the terrestrial fauna varied between -1.5 and $+11.6 \%$. Most of the herbivores clustered between +6.8 and $+11.6 \%$, with the aurochs exhibiting the highest values $(+11.2 \%$ and $+11.6 \%)$ and the red deer among the lowest values $(+6.8$ and $+8.5 \%$ ) (Fig. 6). However, the wild boar was the species displaying the greatest range of values from $-1.5 \%$ o to $+10.3 \%$. As a matter of fact, all the wild boars displaying lower $\delta^{34} \mathrm{~S}$ values than the rest of the fauna originated from the site of Warluis and were the only

2018; Robson pers. comm. 2019), early to late Mesolithic site of Grotte du Paper in Belgium (Drucker et al. 2018), and late Mesolithic site of Noyen-sur-Seine (Drucker et al. 2018). nd stands for not determined
Table 5 Results of collagen extraction yield (yield), elemental (C, N, $\mathrm{C}: \mathrm{N}, \mathrm{C}: \mathrm{S}, \mathrm{N}: \mathrm{S})$, and isotopic $\left(\delta^{13} \mathrm{C}, \delta^{15} \mathrm{~N}, \delta^{34} \mathrm{~S}\right)$ analyses on fish from early Mesolithic site of Friesack 4 in north Germany (Meadows et al.

\begin{tabular}{|c|c|c|c|c|c|c|c|c|c|c|c|c|c|}
\hline Site & $\mathrm{N}^{\circ}$ lab & Species & Sample & Yield (\%) & $\mathrm{C}(\%)$ & $\mathrm{N}(\%)$ & $\mathrm{C}: \mathrm{N}$ & $\delta^{13} \mathrm{C}(\% o)$ & $\delta^{15} \mathrm{~N}(\% o)$ & $\mathrm{S}(\%)$ & $\delta^{34} \mathrm{~S}(\% o)$ & $\mathrm{C}: \mathrm{S}$ & $\mathrm{N}: \mathrm{S}$ \\
\hline Friesack 4 & $\begin{array}{c}\text { F4-4-6a }+ \\
\text { b }\end{array}$ & Eel & Cleithrum & 2.9 & 38.2 & 12.5 & 3.6 & -24.4 & 9.3 & & & & \\
\hline Friesack 4 & F4-3-5a & Perch & $\begin{array}{l}\text { Precaudal } \\
\text { vertebra }\end{array}$ & 6.6 & 38.7 & 14.3 & 3.2 & -25.0 & 7.5 & & & & \\
\hline Friesack 4 & F4-3-6a & Perch & Posttemporal & 10.3 & 42.7 & 14.3 & 3.5 & -26.8 & 10.1 & & & & \\
\hline Friesack 4 & $\begin{array}{c}\mathrm{F} 4-4-1 \mathrm{a}+ \\
\mathrm{b}\end{array}$ & Perch & Ceratohyal & 6.7 & 39.8 & 12.9 & 3.6 & -25.6 & 10.5 & & & & \\
\hline Abri du Pape & BP-16 & Pike & Vertebra & 4.2 & 40.3 & 14.3 & 3.3 & -22.5 & 10.9 & & & & \\
\hline Abri du Pape & BP-20 & Cyprinidae & Vertebra & 2.6 & 34.8 & 12.5 & 3.2 & -21.2 & 8.0 & 0.59 & 4.0 & 156 & 48 \\
\hline Abri du Pape & BP-21 & Cyprinidae & Epihyal & 1.8 & 30.5 & 11.1 & 3.2 & -22.3 & 9.5 & & & & \\
\hline Noyen-sur-Seine & NO7600 & Eel & Vertebra & nd & 40.7 & 14.5 & 3.3 & -23.8 & 8.3 & & & & \\
\hline
\end{tabular}




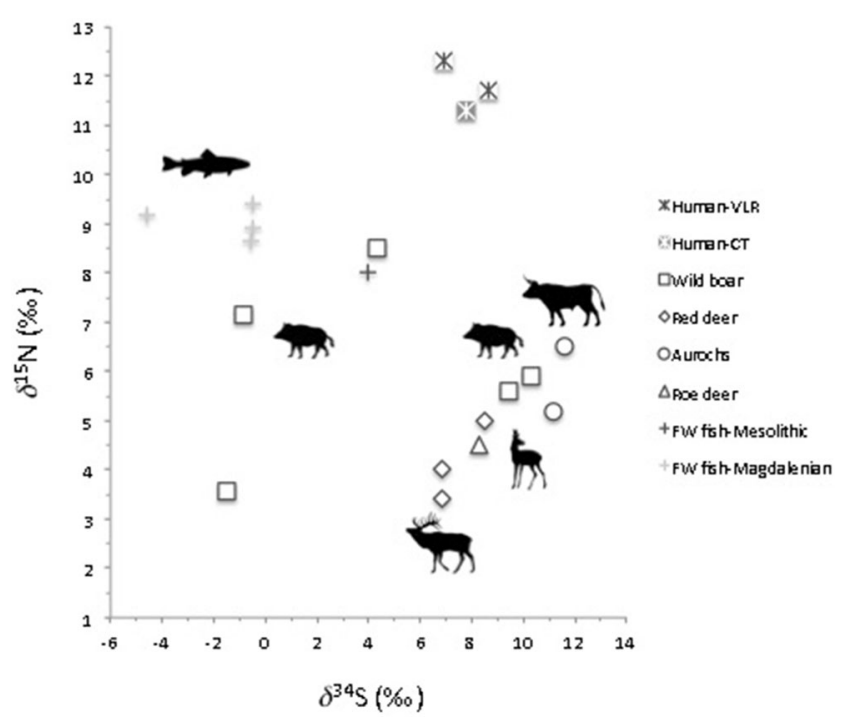

Fig. $6 \delta^{34} \mathrm{~S}$ and $\delta^{15} \mathrm{~N}$ values of red deer (Cervus elaphus), roe deer (Capreolus capreolus), wild boar (Sus scrofa), Aurochs (Bos primigenius), elk (Alces alces) from the Preboreal and Preboreal/Boreal transition, and human individuals from Val-de-Reuil (VLR) and La Chaussée-Tirancourt (CT)

specimens from this site with ${ }^{34} \mathrm{~S}$ results. Warluis is situated in the alluvial plain of Thérain, a tributary of the Oise river, at the limit of the Cretaceous bedrock, the later characterizing the surroundings of the other sites along the Somme river, along with the Paleogene context of Henry-Farman in Paris and some Jurassic formation west to Beauvais (Ducrocq 2017). This particular geological situation could be the origin of the relatively low $\delta^{34} \mathrm{~S}$ values of the wild boar from Warluis.

The $\delta^{34} \mathrm{~S}$ value of one Mesolithic Cyprinid from Grotte du Pape in Belgium was $+4.0 \%$ and thus is comparable with the values of the wild boar from Warluis (Table 5, Fig. 6). Moreover, reporting from the previously published $\delta^{34} \mathrm{~S}$ from the Magdalenian fishes from Belgium $(-4.6 \%$ to $-0.5 \%$ ) confirmed a possible overlap between freshwater and terrestrial resources during the early Holocene. As a result, the ${ }^{34} \mathrm{~S}$ abundances seem to better reflect the geographical origin of some terrestrial resources rather than serve to disentangle the contribution of the freshwater from the high ${ }^{15} \mathrm{~N}$ terrestrial fauna. The $\delta^{34} \mathrm{~S}$ values of the human individuals ranged from +6.9 to $+8.7 \%$ o with VLR-2 showing the lowest value, VLR1 the highest value, and the individual of La ChausséeTirancourt the intermediate one $(+7.8 \%$ o). These values were consistent with those of the fauna, when excluding the wild boar from Warluis. Since the $\delta^{34} \mathrm{~S}$ values do not seem discriminant enough between aquatic and terrestrial ecosystems and may depend significantly on the mobility pattern, we did not use them further for dietary interpretation.

\section{Diet reconstruction based on MixSIAR}

A cluster analysis applied on the $\delta^{13} \mathrm{C}$ and $\delta^{15} \mathrm{~N}$ values of the terrestrial fauna revealed three groups named from the dominant species they included (Figure SD2). The group "red deer" $(n=9)$ corresponded to the herbivores with relatively high $\delta^{13} \mathrm{C}\left(-21.0 \%\right.$ to $-20.1 \%$ ) and the lowest $\delta^{15} \mathrm{~N}$ values (+ $3.4 \%$ to $+5.3 \%$ ), while the group "wild boar" $(n=6)$ encompassed the herbivores with a comparable range of $\delta^{13} \mathrm{C}\left(-20.8\right.$ to $-19.8 \%$ ) but higher $\delta^{15} \mathrm{~N}$ values $(+5.8$ to + $8.5 \%$ ). Finally, the remaining herbivores with the lowest $\delta^{13} \mathrm{C}$ values $\left(-23.3\right.$ to $-21.5 \%$ ) and intermediate $\delta^{15} \mathrm{~N}$ values $(+$ 4.5 to $+7.0 \%$ o $)$ clustered in the "roe deer" group $(n=5)$. For this last group, we did not include the elk specimen in the calculation of the isotopic average since it was of natural origin and not associated to human subsistence activity (see also Bridault 1992). The fish specimens $(n=8)$ were considered as a separate group from the terrestrial ones with their relatively low $\delta^{13} \mathrm{C}(-26.8 \%$ to $-21.2 \% 0)$ and high $\delta^{15} \mathrm{~N}$ values (+ $7.5 \%$ to $+10.9 \%$ ). The niche reconstruction provided by the SIBER analysis validated the terrestrial and aquatic grouping described above since it confirmed that the defined prey groups belong to different core niches (Fig. 5).

The results of the simulation provided a rather similar pattern for the two individuals of Val-de-Reuil(Fig. 7). Both freshwater and wild boar clusters may have contributed substantially to their diet, with means of $24.4 \pm 19.5 \%$ (median $18.9 \%$ ) and $40.6 \pm 24.9 \%$ (median $40.4 \%$ ), respectively, for VLR-1, and of $31.0 \pm 21.5 \%$ (median $27.9 \%$ ) and $35.3 \pm$ $23.5 \%$ (median $33.5 \%$ ), respectively, for VLR-2. These two resource groups showed a negative correlation in their posterior distribution, meaning that a higher proportion of one involves a lower proportion of the other, without further possible discrimination between the different scenarios based on the model. So far, the chronological evidence of high $\delta^{15} \mathrm{~N}$ wild boar apparently post-dated the chronological position of the individuals of Val-de-Reuil, even in the hypothesis of a reservoir effect correction. Interestingly, the increasing presence of the wild boar among the hunted preys seems to start only at the Preboreal to Boreal transition (Bridault 1997; Coutard et al. 2010; Ducrocq et al. 2014). If we favor the hypothesis of a higher contribution of the freshwater resources over the wild boar, we find the expected higher aquatic product consumption in VLR-2 rather than in VLR-1, which would be consistent with a reservoir effect biased gap between the radiocarbon ages of the two individuals. In any case, the potential intake of roe deer and red deer groups as prey appeared minor for the human individuals from Val-de-Reuil, at least not exceeding $25 \%$ of the protein part of the diet (Fig. 7).

The combinations of prey groups tested for the human of $\mathrm{La}$ Chaussée-Tirancourt showed a possible main input of the freshwater and wild boar clusters (Fig. 7). The freshwater group could have contributed to $29.7 \pm 15.3 \%$ of the dietary protein on 

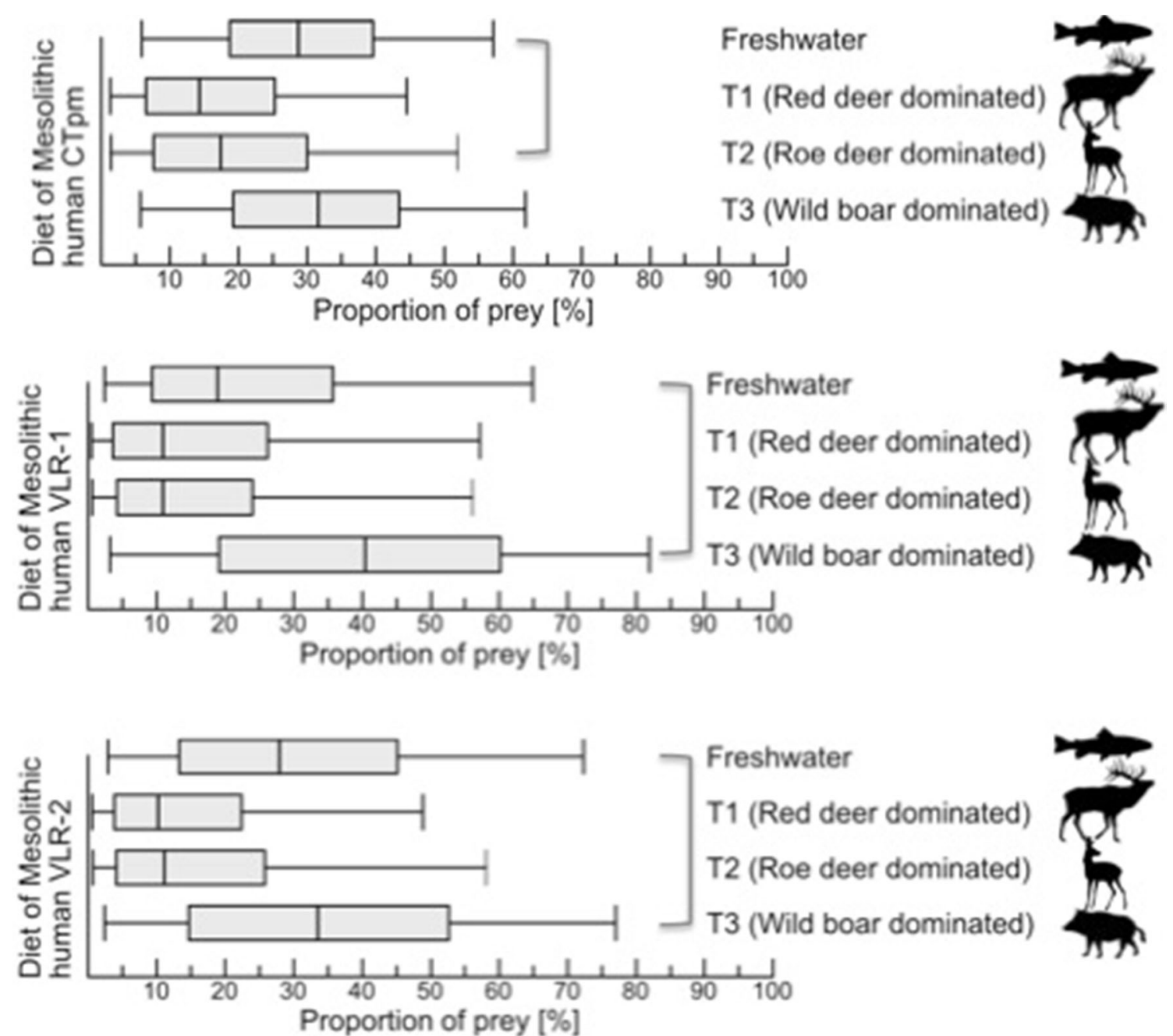

Fig. 7 Results of the MixSIAR model simulation of the relative contribution of the different prey groups. The brackets connect the resources with a significant negative correlation in their posterior distribution

average (median value of $28.7 \%$ ), while the wild boar group could have provided $32.2 \pm 17.0 \%$ on average (median value of $31.6 \%$ ). However, a negative correlation could be noticed between the freshwater group and the roe deer group. This last cluster, corresponding mainly to forest-dwelling prey, could represent a mean of $20.5 \pm 15.9 \%$ (17.4\% as median value), which was comparable with the red deer group whose input could be $17.5 \pm 13.8 \%$ (median value of $14.3 \%$ ). So far, no consumption of aquatic resources could be attested for through zooarchaeological evidence from the early Mesolithic in northern France, where remains of fish have not been found before the end of the Boreal occupation (Ducrocq et al. 2008; Ducrocq 2014). Thus, the roe deer group could be a convincing alternative to aquatic resources when dealing with human diet by the end of the Preboreal, which would be consistent with the increasing role of the forested areas in the subsistence of the Mesolithic huntergatherers over the early Holocene (Coutard et al. 2010). Although archaeofauna dated to the Preboreal are still poorly documented in northern France, it is interesting to note that roe deer is the second preyed upon species at Warluis IIIb (Bridault unpublished) and the first one at Les Closeaux IV (Bridault unpublished) and Warluis IIIa (Bridault unpublished) in the Paris Basin. A contribution of roe deer in the human diet during the Preboreal is thus consistent with the archaeozoological observations to date. 
Fig. $8 \delta^{13} \mathrm{C}$ and $\delta^{15} \mathrm{~N}$ values of human (individual data) and fauna (averages and standard deviations) from northern France (this work), western France (Schulting et al. 2008), Belgium (Bocherens et al. 2007), southern North Sea (van der Plicht et al. 2016), and northern Germany (Meadows et al. 2018) during the Preboreal.

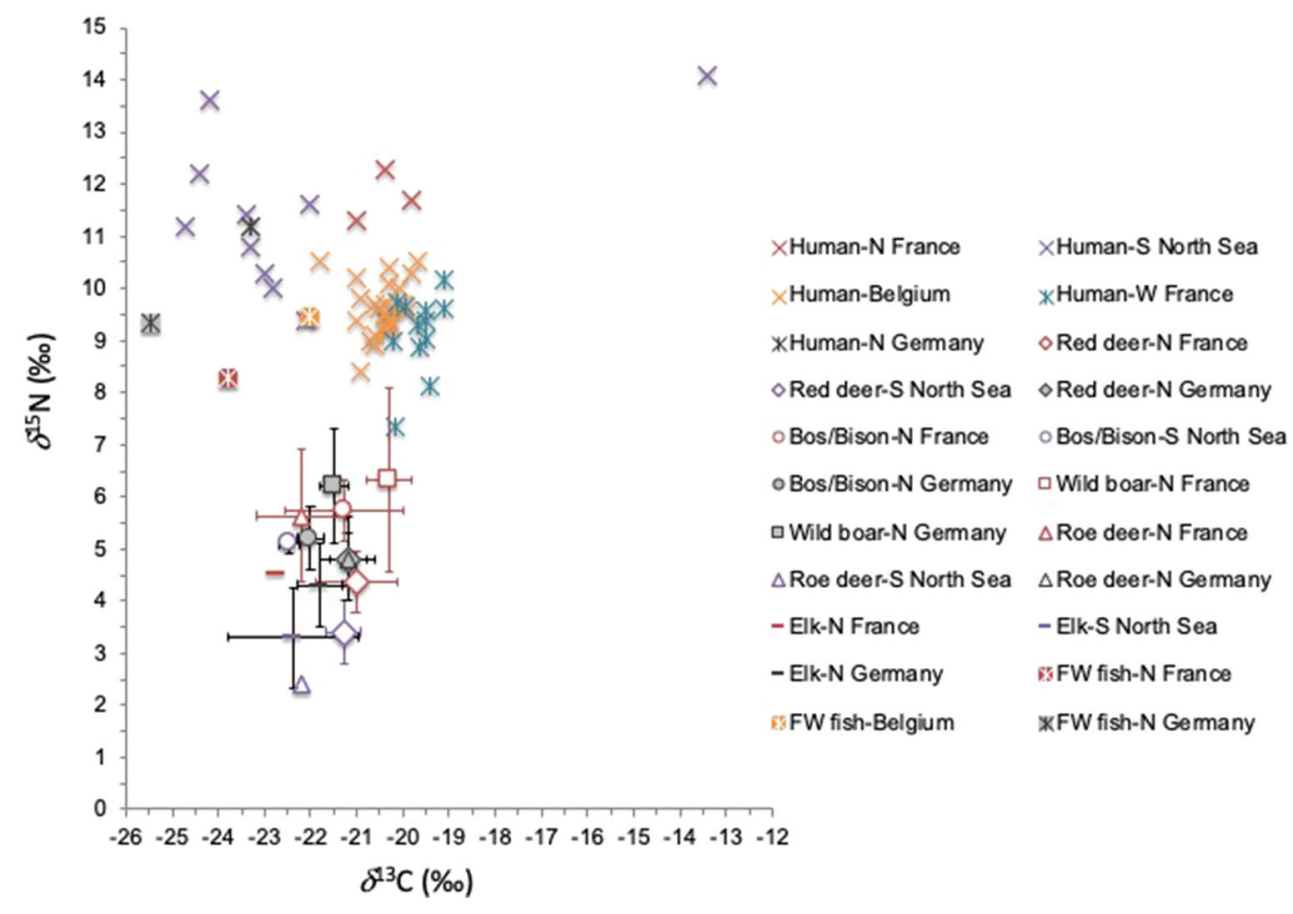

\section{Diet reconstruction in the context of the early Holocene}

Investigation into early Mesolithic human diet based on collagen stable isotopes has been conducted in other inland contexts, such as the Doggerland (currently North Sea), the Meuse Basin in Belgium, the site of La Vergne in western France, and Friesack in north Germany (Bocherens et al. 2007; Schulting et al. 2008, van der Plicht et al. 2016, Meadows et al. 2018; Fig. 8). When possible, we have reported the results of the associated fauna in addition to those of human individuals to take into consideration possible biases linked to a difference in the local baseline. We have not observed significant contrasts in the $\delta^{13} \mathrm{C}$ and $\delta^{15} \mathrm{~N}$ values according to location. The only notable exception would be the roe deer with a difference of ca. 3\%o between northern France and the North Sea, but the comparison may be biased since only one specimen was analyzed in the North Sea. We can thus consider a direct comparison for the human individuals. Remains from animal and human bones from the North Sea were directly dated, and a number of them were found to belong to the Preboreal period, from ca. 10,000 to 8900 BP (ca. 11,500-10,000 cal BP). Most of them delivered higher $\delta^{15} \mathrm{~N}$ values than those expected for the consumption of the chronologically associated fauna for comparable or lower $\delta^{13} \mathrm{C}$ values, pointing to significant consumption of freshwater resources (van der Plicht et al. 2016). For the same time range, one individual provided remarkably high $\delta^{13} \mathrm{C}$ and $\delta^{15} \mathrm{~N}$ values revealing an additional contribution of the marine resources in the diet. In Belgium, the region of the Meuse Basin is rich in Mesolithic human remains belonging to the early phases of the Mesolithic, and a terrestrial-based diet was inferred from the relative abundances of ${ }^{13} \mathrm{C}$ and ${ }^{15} \mathrm{~N}$ in their collagen (Bocherens et al. 2007). Their $\delta^{13} \mathrm{C}$ and $\delta^{15} \mathrm{~N}$ values were indeed significantly lower than those of the individuals consuming freshwater food from the North Sea. The same conclusion applies to the western French site of $\mathrm{La}$ Vergne where several early Mesolithic individuals, all directly dated, could be analyzed (Schulting et al. 2008). Their $\delta^{15} \mathrm{~N}$ values were comparable to those of the Meuse Basin, while their $\delta^{13} \mathrm{C}$ values were slightly higher which could indicate a more open habitat for the consumed terrestrial prey. Finally, the early Mesolithic adult from Friesack 4 showed ${ }^{13} \mathrm{C}$ and ${ }^{15} \mathrm{~N}$ relative abundances fitting in the range of the freshwater resources consumers of the North Sea, which is consistent with the conclusion of large freshwater ecosystem contribution drawn from the study of Meadows et al. (2018).

The humans from northern France provided higher $\delta^{15} \mathrm{~N}$ values than the individuals from the Meuse Basin and western France, which is consistent with a contribution of freshwater resources and/or high ${ }^{15} \mathrm{~N}$ terrestrial prey. Their $\delta^{13} \mathrm{C}$ values were higher than those of the North Sea, which should again be interpreted as a contribution of more terrestrial prey but also could be attributed to the high variability in ${ }^{13} \mathrm{C}$ of the freshwater resources as illustrated by the fish data reported in Fig. 8. An alternative scenario would be the occurrence of additional marine resources in the diet. However, the measured $\delta^{34} \mathrm{~S}$ values do not support such a hypothesis, since those of the human individuals were comparable with those of most of the terrestrial fauna and were not shifted toward higher values. We thus consider the consumption of freshwater resources as being a possible scenario for the humans from 
northern France, especially for the individuals from Val-deReuil.

\section{Conclusions and perspectives}

The Preboreal proves to be a key period for the change in herbivore habitat. In northern France, the $\delta^{13} \mathrm{C}$ and $\delta^{15} \mathrm{~N}$ values of the large deer species clearly reflect a transition to dense forest and more productive vegetation sustained by developing soils. The rapid change at the scale of the radiocarbon dating results in a complex baseline with terrestrial resources potentially difficult to distinguish from the aquatic resources. The $\delta^{34} \mathrm{~S}$ values may not be a helpful tracker in this context, since they seem to depend more on the location of the prey than on the ecosystem (terrestrial versus aquatic) they belong to. However, if such geographic contrast in ${ }^{34} \mathrm{~S}$ relative abundances could be confirmed, such as on other species than wild boar at the site of Warluis, they could represent a promising tool for reconstructing the mobility of the animals and their predators, including human groups. If the MixSIAR calculations do not rule out or confirm the consumption of aquatic resources, they may point to the increasing influence of the forest ecosystem on the human subsistence. Besides, the different possible scenarios are consistent with a diversified diet in terms of source of meat protein. If the consumption of aquatic resources can be suspected, especially in the case of the individuals of Val-deReuil, the use of other meat resources was not otherwise disregarded. The whole range of opportunities to access animal protein may have been exploited.

Acknowledgements We would like to thank Cyrille Billard for his support in the study of the site of Val-de-Reuil, as well as Jean-Pierre Fagnart and Paule Coudret for the access to the material of the site of Belloy-surSomme and Saleux. The collagen preparation and analysis benefited from the technical assistance of Issam Moussa (ISEM, University of Montpellier 2), Bernd Steinhilber, (AG Isotopengeochemie, University of Tübingen), and the team of AG Biogeologie (University of Tübingen). The manuscript has benefited from the comments of two reviewers, and the proofreading of Peter Tung (S-HEP Tübingen, University of Tübingen).

Funding information Open Access funding provided by Projekt DEAL. This work was supported by the project ECLIPSE (2001-2003, No. 0693, coord. A. Bridault), IFB project "Changement global, biodiversité animale et sociétés humaines dans la moitié nord de la France depuis 16000 ans" (2004-2006, No. 0403, coord. A. Bridault), and INRAP project PAS "Environnement et réseau trophique au début du Mésolithique : une approche isotopique d'après les données des gisements des vallées tourbeuses du Nord de la France" (2016-2017, R110068, coord. T. Ducrocq).

Open Access This article is licensed under a Creative Commons Attribution 4.0 International License, which permits use, sharing, adaptation, distribution and reproduction in any medium or format, as long as you give appropriate credit to the original author(s) and the source, provide a link to the Creative Commons licence, and indicate if changes were made. The images or other third party material in this article are included in the article's Creative Commons licence, unless indicated otherwise in a credit line to the material. If material is not included in the article's Creative Commons licence and your intended use is not permitted by statutory regulation or exceeds the permitted use, you will need to obtain permission directly from the copyright holder. To view a copy of this licence, visit http://creativecommons.org/licenses/by/4.0/.

\section{References}

Ambrose SH (1990) Preparation and characterization of bone and tooth collagen for isotopic analysis. J Archeol Sci 17(4):431-451

Antoine P, Lautridou JP, Laurent M (2000)Long-term fluvial archives in NW France: response of the Seine and Somme rivers to tectonic movements, climatic variations and sea-level changes. Geomorphology 33(3-4):183-207

Antoine P, Locht J-L, Limondin-Lozouët N, Auguste P, Bahain J-J, Goval E, Fagnart J-P, Debenham N, Ducrocq T (2014) Quaternaire et géoarchéologie de la Préhistoire. Le modèle de la vallée de la Somme et des régions avoisinantes. https://doi.org/10. 4000/books.editionscnrs.21954

Antoine P, Locht JL, Limondin-Lozouet N, Auguste P, Bahain JJ, Goval É, Fagnart JP, Debenham N, Ducrocq T (2015) Quaternary geoarchaeology and prehistory. The model of the Somme valley (France) and the neighbouring regions. In: Arnaud-Fasseta G, Carcaud N (eds) French geoarchaeology in the $21^{\text {st }}$ century. CNRS EDITIONS Alpha, Paris, pp 71-86

Baubet E, Bonenfant C, Brandt S (2004) Diet of the wild boar in the French Alps. Galemys 16:101-113

Baumann C, Starkovich BM, Drucker DG, Münzel SC, Conard NJ, Bocherens H (2020) Dietary niche partitioning among Magdalenian canids in southwestern Germany and Switzerland. Quat Sci Rev 227:106032

Bazanella M, Betti L, Wierer U (2007) Mesolithic wetland exploitation at Galgenbühel / Dos de la Forca Italy, Eastern Alps. The fish fauna. In: Plogmann HH (ed) The role of fish in ancient time. Marie Leidorf GmbH, Rahden/Westf, pp 93-100.

Billard C, Arbogast RM, Valentin F, Querré G, Barriel V (2001) La sépulture mésolithique des Varennes à Val-de-Reuil (Eure). Bull Soc préhist fr 98(1):25-52

Bocherens H (2009) Neanderthal dietary habits: review of the isotopic evidence. The evolution of Hominin diets Springer, Dordrecht, In, pp 241-250

Bocherens H, Drucker D (2003) Trophic level isotopic enrichment of carbon and nitrogen in bone collagen: case studies from recent and ancient terrestrial ecosystems. Int J Osteoarchaeol 13(1-2):46-53

Bocherens H, Billiou D, Patou-Mathis M, Bonjean D, Otte M, Mariotti A (1997) Paleobiological implications of the isotopic signatures $\left({ }^{13} \mathrm{C}\right.$, ${ }^{15} \mathrm{~N}$ ) of fossil mammal collagen in Scladina Cave (Sclayn, Belgium). Quat Res 48(3):370-380

Bocherens H, Polet C, Toussaint M (2007) Palaeodiet of Mesolithic and Neolithi populations of Meuse Basin (Belgium): evidence from stable isotopes. J Archeol Sci 34(1):10-27

Bocherens H, Drucker DG, Germonpré M, Lázničková-Galetová M, Naito YI, Wissing C, Brůžek J, Oliva M (2015) Reconstruction of the Gravettian food-web at Předmostí I using multi-isotopic tracking $\left({ }^{13} \mathrm{C},{ }^{15} \mathrm{~N},{ }^{34} \mathrm{~S}\right)$ of bone collagen. Quat Int 359:211-228

Boethius A, Storå J, Vala CH, Apel J (2017) The importance of freshwater fish in Early Holocene subsistence: Exemplified with the human colonization of the island of Gotland in the Baltic basin. J Archaeol 13:625-634 
Bonsall C, Cook GT, Hedges RE, Higham TF, Pickard C, Radovanović I (2004) Radiocarbon and stable isotope evidence of dietary change from the Mesolithic to the Middle Ages in the Iron Gates: new results from Lepenski Vir. Radiocarbon 46(1):293-300

Bridault A (1992) The status of elk during the Mesolithic. Anthropozoologica 16:151-160

Bridault A (1994) Les économies de chasse épipaléolithiques et mésolithiques du Nord et de l'Est de la France : nouvelles analyses. Anthropozoologica 19:55-67

Bridault A (1997) Chasseurs, ressources animales et milieux dans le Nord de la France de la fin du Paléolithique à la fin du Mésolithique. In: Fagnart J-P, Thévenin A (eds) Le Tardiglaciaire en Europe du nordouest, Actes du $119 \mathrm{e}$ congrès annuel des sociétés historiques et scientifiques, Amiens, octobre 1994, éd. CTHS, Paris, pp 166-176

Bronk Ramsey C (2017) Methods for summarizing radiocarbon datasets. Radiocarbon 59(2): 1809-1833

Clarke DL (1976) Mesolithic Europe: the economic basis. In: Longworth $\mathrm{IH}$, Wilson KE (eds) Sievking G de G. Problems in economic and social archaeology, Duckworth, London, pp 449-481

Coutard S, Ducrocq T, Limondin-Lozouet N, Bridault A, Leroyer C, Allenet G, Pastre JF (2010) Contexte géomorphologique, chronostratigraphique et paléoenvironnemental des sites mésolithiques et paléolithiques de Warluis dans la vallée du Thérain (Oise, France). Quaternaire 21(4):357-384

Craine JM, Elmore AJ, Aidar MP, Bustamante M, Dawson TE, Hobbie EA, Kahmen A, Mack MC, McLauchlan KK, Michelsen A, Nardoto GB (2009) Global patterns of foliar nitrogen isotopes and their relationships with climate, mycorrhizal fungi, foliar nutrient concentrations, and nitrogen availability. New Phytol 183(4):980 992

Craine JM, Brookshire ENJ, Cramer MD, Hasselquist NJ, Koba K, Marin-Spiotta E, Wang L (2015) Ecological interpretations of nitrogen isotope ratios of terrestrial plants and soils. Plant Soil 396:1-26

De Beaulieu JL, Richard H, Ruffaldi P, Clerc J (1994) History of vegetation, climate and human action in the French Alps and the Jura over the last 15000 years. Diss Botanicae 234:253-276

DeNiro MJ (1985) Postmortem preservation and alteration of in vivo bone collagen isotope ratios in relation to palaeodietary reconstruction. Nature 317(6040):806-809

Drucker DG, Bridault A, Hobson KA, Szuma E, Bocherens H (2008) Can carbon-13 in large herbivores reflect the canopy effect in temperate and boreal ecosystems? Evidence from modern and ancient ungulates. Palaeogeogr Palaeoclimatol Palaeoecol 266(1-2):69-82

Drucker DG, Bridault A, Cupillard C, Hujic A, Bocherens H (2011) Evolution of habitat and environment of red deer (Cervus elaphus) during the Late-glacial and early Holocene in eastern France (French Jura and the western Alps) using multi-isotope analysis $\left(\delta^{13} \mathrm{C}, \delta^{15} \mathrm{~N}\right.$, $\left.\delta^{18} \mathrm{O}, \delta^{34} \mathrm{~S}\right)$ of archaeological remains. Quat Int 245(2):268-278

Drucker DG, Rosendahl W, Van Neer W, Weber MJ, Görner I, Bocherens H (2016) Environment and subsistence in northwestern Europe during the Younger Dryas: An isotopic study of the human of Rhünda (Germany). J Archeol Sci Rep 6:690-699

Drucker DG, Valentin F, Thevenet C, Mordant D, Cottiaux R, Delsate D, Van Neer W (2018) Aquatic resources in human diet in the Late Mesolithic in Northern France and Luxembourg: insights from carbon, nitrogen and sulphur isotope ratios. Archeol Anthropol Sci 10(2):351-368

Ducrocq T (2014) The complex evolution of the Mesolithic in Picardie. In: Henry A, Marquebielle B, Chesnaux L, Michel S (eds) Techniques and Territories: New Insights into Mesolithic Cultures, Proceedings of the Round table, November 22-23 2012, P@lethnology 6. Maison de la recherche, Toulouse, pp 89-95

Ducrocq T (2017) Vue d'ensemble des fosses mésolithiques dans les Hauts-de-France. In: Achard-Corompt N, Ghesquière E, Riquier V (eds) Digging in the Mesolithic, Séances de la Société préhistorique française, 12. Société préhistorique française, Paris, pp 173-188
Ducrocq T, Le Goff I, Valentin F (1996) La sépulture secondaire mésolithique de la Chaussée-Tirancourt (Somme). Bull Soc préhist fr 93(2):211-216

Ducrocq T, Bridault A, Coutard S (2008) Le gisement mésolithique de Warluis : approche préliminaire. In: Fagnart J-P, Thévenin A, Ducrocq T, Souffi B, Coudret P (eds), Le début du Mésolithique en Europe du Nord-Ouest, Actes de la table ronde, Amiens, 9-10 octobre 2004. Paris, Mém Soc préhist fr 45:85-106

Ducrocq T, Bridault A, Cayol N, Coutard S (2014) Une concentration de vestiges caractéristiques du Beuronien à segments: le gisement de Warluis I (Oise). RAP 1-2:5-42

Fernandes R, Rinne C, Nadeau MJ, Grootes P (2016) Towards the use of radiocarbon as a dietary proxy: establishing a first wide-ranging radiocarbon reservoir effects baseline for Germany. Environ Archaeol 21(3):285-294

Feurdean A, Perșoiu A, Tanțău I, Stevens T, Magyari EK, Onac BP, Marković S, Andrič M, Connor S, Fărcaș S, Gałka M (2014) Climate variability and associated vegetation response throughout Central and Eastern Europe (CEE) between 60 and 8 ka. Quat Sci Rev 106:206-224

Fischer A, Olsen J, Richards M, Heinemeier J, Sveinbjörnsdóttir ÁE, Bennike P (2007)Coast-inland mobility and diet in the Danish Mesolithic and Neolithic: evidence from stable isotope values of humans and dogs. J Archeol Sci 34(12):2125-2150

Frontin D (2017) Économie de pêche au Mésolithique et diversité piscicole à l'Holocène ancien dans le bassin hydrographique du Doubs. Doctoral Dissertation, Université Paris1-PanthéonSorbonne.

Gearey BR, Hopla EJ, Boomer I, Smith D, Marshall P, Fitch S, Griffiths S, Tapping DR (2017)Multi-proxy palaeoecological approaches to submerged landscapes: a case study from 'Doggerland', in the southern North Sea. In: Williams M, Hill T, Boomer I, Wilkinson IP (eds) The archaeological and forensic applications of microfossils: a deeper understanding of human history. The Micropalaeontological Society, Special Publications, Geological Society, London, London, pp 35-53

Gelman A, Carlin J, Stern H, Dunson D, Vehtari A, Rubin D (2014) Bayesian Data Analysis. Chapman and Hall, New York

Guiry EJ (2019) Complexities of stable carbon and nitrogen isotope biogeochemistry in ancient freshwater ecosystems: implications for the study of past subsistence and environmental change. Front Ecol Evol 7:313

Guiry EJ, Hillier M, Boaventura R, Silva AM, Oosterbeek L, Tomé T, Valera A, Cardoso JL, Hepburn JC, Richards MP (2016) The transition to agriculture in south-western Europe: new isotopic insights from Portugal's Atlantic coast. Antiquity 90(351):604-616

Hedges REM, Reynard LM (2007) Nitrogen isotopes and the trophic level of humans in archaeology. J Archeol Sci 34(8):1240-1251

Hobbie EA, Högberg P (2012) Nitrogen isotopes link mycorrhizal fungi and plants to nitrogen dynamics. New Phytol 196(2):367-382

Hobbie EA, Jumpponen A, Trappe J (2005) Foliar and fungal ${ }^{15} \mathrm{~N}:{ }^{14} \mathrm{~N}$ ratios reflect development of mycorrhizae and nitrogen supply during primary succession: testing analytical models. Oecologia 146: 258-268

Inger R, Jackson A, Parnell A, Bearhop S (2010) SIAR v4 (Stable Isotope Analysis in R): an ecologist's guide. Dublin, Ireland

Jackson AL, Inger R, Parnell AC, Bearhop S (2011) Comparing isotopic niche widths among and within communities: SIBER-Stable Isotope Bayesian Ellipses in R. J Anim Ecol 80(3):595-602

Jarman MR (1972) European deer economies and the advent of the Neolithic. In: Higgs ES (ed) Papers in economic prehistory. Cambridge University Press, Cambridge, pp 125-148

Kohn MJ (2016) Carbon isotope discrimination in C3 land plants is independent of natural variations in pCO2. Geophys Perspect Lett 2:35-43 
Krajcarz MT, Krajcarz M, Drucker DG, Bocherens H (2019)Prey-to-fox isotopic enrichment of $34 \mathrm{~S}$ in bone collagen: Implications for palaeoecological studies. Rapid Commun Mass Spectrom 33: $1311-1317$

Krüger S, Dörfler W, Bennike O, Wolters S (2017) Life in Doggerlandpalynological investigations of the environment of prehistoric hunter-gatherer societies in the North Sea Basin. E \& G Quat Sci J 66(1):3-13

Layman CA, Arrington DA, Montaña CG, Post DM (2007) Can stable isotope ratios provide for community-wide measures of trophic structure? Ecology 88(1):42-48

Leduc C, Bridault A, Souffi B, David É, Drucker DG (2013) Apports et limites de l'étude des vestiges fauniques à la caractérisation d'un site mésolithique de plein air à Paris:«62 rue Henry-Farman»(15 e arrondissement). Bull Soc préhist fr 110(2):257-280

Lillie MC, Richards M (2000) Stable isotope analysis and dental evidence of diet at the Mesolithic-Neolithic transition in Ukraine. J Archeol Sci 27(10):965-972

Longin R (1971) New method of collagen extraction for radiocarbon dating. Nature 230(5291):241-242

Lubell D, Jackes M, Schwarcz H, Knyf M, Meiklejohn C (1994) The Mesolithic-Neolithic transition in Portugal: isotopic and dental evidence of diet. J Archeol Sci 21(2):201-216

Männel TT, Auerswald K, Schnyder H (2007) Altitudinal gradients of grassland carbon and nitrogen isotope composition are recorded in the hair of grazers. Glob Ecol Biogeogr 16:583-592

Marinval-Vigne M-C, Mordant D, Auboire G, Augereau A, Bailon S, Dauphin C, Delibrias G, Krier V, Leclerc A-S, Leroyer C, Marinval P, Mordant C, Rodriguez P, Vilette P, Vigne JD(1989)Noyen-sur- Seine, site stratifié en milieu fluviatile: une étude multidisciplinaire intégrée. Bull Soc Préhi Fr 86:370-379

Meadows J, Robson HK, Groß D, Hegge C, Lübke H, Schmölcke U, Terberger T, Gramsch B (2018) How fishy was the inland Mesolithic? New data from Friesack, Brandenburg, Germany. Radiocarbon 60(5):1621-1636

Nehlich O (2015) The application of sulphur isotope analyses in archaeological research: a review. Earth-Sci Rev 142:1-17

Nehlich O, Richards MP (2009) Establishing collagen quality criteria for sulphur isotope analysis of archaeological bone collagen. Archeol Anthropol Sci 1(1):59-75

Pastre JF, Leroyer C, Limondin-Lozouet N, Antoine P, Gauthier A, Le Jeune Y, Orth P (2003) Quinze mille ans d'environnement dans le Bassin parisien (France): mémoires sédimentaires des fonds de vallée. Des milieux et des hommes: fragments d'histoires croisés, Elsevier, Mayenne, pp:43-55

Price TD (1987) The Mesolithic of Western Europe. J World Prehist 1: 227-305

Privat KL, O'Connell TC, Hedges REM (2007) The distinction between freshwater-and terrestrial-based diets: methodological concerns and archaeological applications of sulphur stable isotope analysis. J Archeol Sci 34(8):1197-1204

Reimer PJ, Bard E, Bayliss A, Beck JW, Blackwell PG, Ramsey CB, Buck CE, Cheng H, Edwards RL, Friedrich M, Grootes PM (2013) IntCal13 and Marine13 radiocarbon age calibration curves 0-50,000 years cal BP. Radiocarbon 55(4):0.1869-0.1887
Richards MP (2002) A brief review of the archaeological evidence for Palaeolithic and Neolithic subsistence. Eur J Clin Nutr 56(12):1270 1278

Richards MP, Fuller BT, Hedges REM (2001) Sulfur isotopic variation in ancient bone collagen from Europe: implications for human palaeodiet, residence mobility, and modern pollutant studies. Earth Planet Sci Lett 191:185-190

Richards MP, Price TD, Koch E (2003) Mesolithic and Neolithic subsistence in Denmark: new stable isotope data. Curr Anthropol 44(2): 288-295

Schley L, Roper TJ (2003) Diet of wild boar Sus scrofa in Western Europe, with particular reference to consumption of agricultural crops. Mammal Rev 33(1):43-56

Schmitt J, Schneider R, Elsig J, Leuenberger D, Lourantou A, Chappellaz J, Köhler P, Joos F, Stocker TF, Leuenberger M, Fischer H (2012) Carbon isotope constraints on the deglacial $\mathrm{CO}_{2}$ rise from ice cores. Science 336(6082):711-714

Schoeninger MJ, DeNiro MJ (1984) Nitrogen and carbon isotopic composition of bone collagen from marine and terrestrial animals. Geochim Cosmochim Acta 48(4):625-639

Schulting R (2011)Mesolithic-Neolithic Transitions: An Isotopic Tour through Europe. In: Pinhasi R, Stock JT (eds) Human bioarchaeology of the transition to agriculture. Willey, London, pp $15-41$

Schulting RJ, Blockley SM, Bocherens H, Drucker D, Richards M (2008) Stable carbon and nitrogen isotope analysis on human remains from the Early Mesolithic site of La Vergne (Charente-Maritime, France). J Archeol Sci 35(3):763-772

Stock BC, Semmens BX (2016) MixSIAR GUI User Manual v3.1. Scripps Institution of Oceanography, UC San Diego

Terberger T, Gramsch B, Heinemeier J (2012) The underestimated fish? Early Mesolithic human remains from Northern Germany. In: Niekus MJL, Barton RNE, Street M, Terberger T (eds) A Mind Set on flint. Studies in Honour of Dick Stapert, Groningen, pp 343-354

Terberger T, Burger J, Lüth F, Müller J, Piezonka H (2018) Step by stepThe neolithisation of Northern Central Europe in the light of stable isotope analyses. J Archeol Sci 99:66-86

Valentin F (1995) Le squelette mésolithique du Petit Marais de la Chaussée-Tirancourt (Somme, France). C.R. Acad. Sci. Paris 321(11):1063-1067

Van der Plicht J, Amkreutz LWSW, Niekus MT, Peeters JHM, Smit BI (2016) Surfn Turf in Doggerland: Dating, stable isotopes and diet of Mesolithic human remains from the southern North Sea. J Archeol Sci Rep 10:110-118

Van Klinken GJ (1999) Bone collagen quality indicators for palaeodietary and radiocarbon measurements. J Archeol Sci 26(6): 687-695

Wißing C, Rougier H, Baumann C, Comeyne A, Crevecoeur I, Drucker DG, Gaudzinski-Windheuser S, Germonpré M, Gómez-Olivencia A, Krause J, Matthies T (2019) Stable isotopes reveal patterns of diet and mobility in the last Neandertals and first modern humans in Europe. Sci Rep 9(1):1-12

Publisher's note Springer Nature remains neutral with regard to jurisdictional claims in published maps and institutional affiliations. 